Discussion

Papers

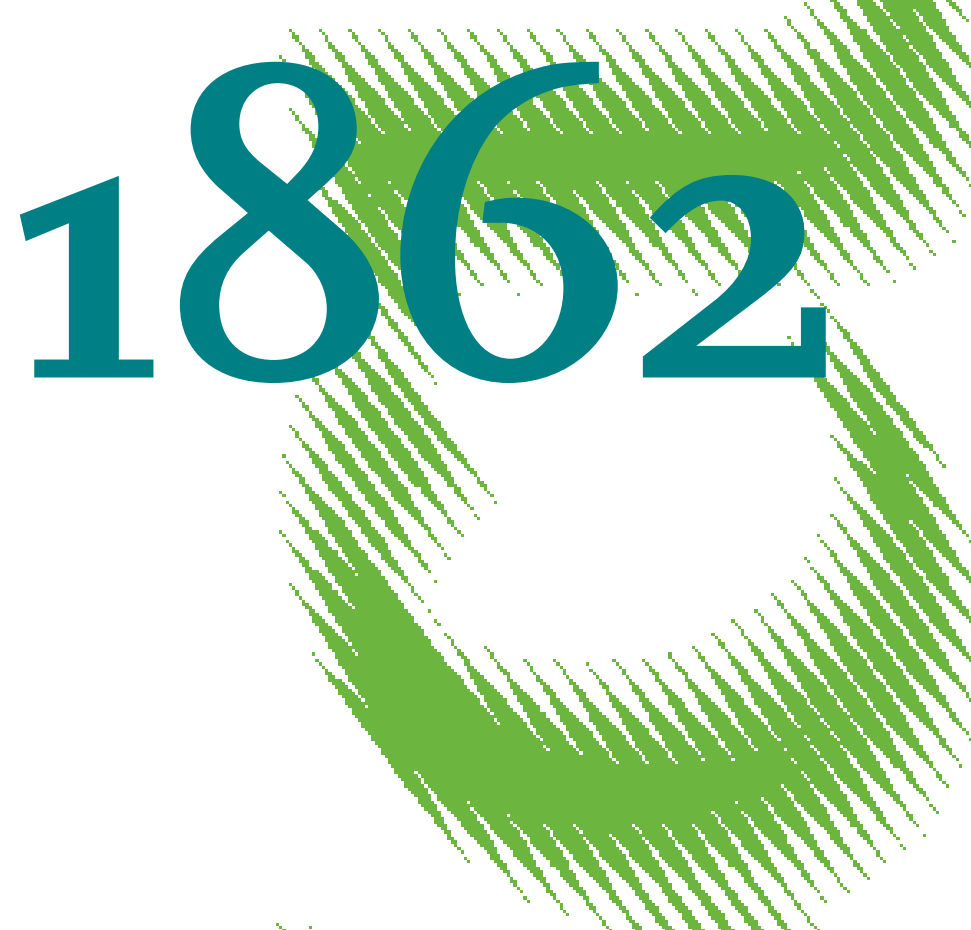

Insolvency Regimes and Cross-Border Investment Decisions 
Opinions expressed in this paper are those of the author(s) and do not necessarily reflect views of the institute.

IMPRESSUM

(C) DIW Berlin, 2020

DIW Berlin

German Institute for Economic Research

Mohrenstr. 58

10117 Berlin

Tel. +49 (30) $89789-0$

Fax +49 (30) $89789-200$

http://www.diw.de

ISSN electronic edition 1619-4535

Papers can be downloaded free of charge from the DIW Berlin website:

http://www.diw.de/discussionpapers

Discussion Papers of DIW Berlin are indexed in RePEc and SSRN:

http://ideas.repec.org/s/diw/diwwpp.html

http://www.ssrn.com/link/DIW-Berlin-German-Inst-Econ-Res.html 


\title{
Insolvency Regimes and Cross-Border Investment Decisions
}

\author{
Tatsiana Kliatskova*
}

Loïc Baptiste Savatier**

This version: April 2020

\begin{abstract}
This paper investigates the effect of reforms of insolvency regulations on cross-border debt and equity investments at a sectoral level. Using disaggregated data from the Securities Holdings Statistics by Sector (SHSS) and OECD-indicators on the efficiency of insolvency regulations, we find that investors prefer to invest more in countries with more efficient insolvency frameworks. The effect, however, differs across sectors, with households and institutional investors being particularly sensitive. In addition, shareholders are mostly responsive to prevention and streamlining tools, while debt-holders respond more to availability of restructuring tools. Finally, we show that countries with developed financial markets and effective government are the ones that see the largest debt and equity inflows after reforms of insolvency regulations.
\end{abstract}

Keywords: capital market integration, insolvency law, sectoral effects JEL Codes: F21, G15, G33

\footnotetext{
* At the time of writing: Research Associate at the DIW Berlin. Current affiliation: Economist, The World Bank Group, tkliatskova@worldbank.org.

** At the time of writing: Research Intern at the Directorate General Financial Stability of Deutsche Bundesbank. This paper was written in the context of the SAW-project "European capital markets and macroeconomic stability: The role of equity and debt." Funding from the Leibniz Competition is gratefully acknowledged. The paper was written during internships at the Deutsche Bundesbank. We thank Deutsche Bundesbank for giving us access to the Securities Holdings Statistics by Sector data. We are grateful to Thomas Droll, Melanie Wulff, Franziska Bremus, and seminar participants at the Deutsche Bundesbank for their helpful comments and suggestions. The views expressed here are those of the authors and do not necessarily represent or reflect the views of the Deutsche Bundesbank and the World Bank Group.
} 


\section{Introduction}

The EU financial system remains national and cross-border financial integration is rather limited (European Commission, 2015b). To promote capital market integration in the EU, the Capital Markets Union project was launched in 2015. Important impediments on the way to the common EU capital market are differences in financial services regulations and institutional quality, and particularly differences in and efficiencies of insolvency procedures (European Commission, 2015a). On June 20, 2019, the European Parliament and Council signed a new Directive 2019/1023 ${ }^{1}$ that establishes minimum standards for preventive restructuring procedures that should be adopted at a national level. The Directive sets early restructuring procedures that are beneficial for enterprises as it allows them to continue operating while being in distress as well as maximizes their value. In addition, it introduces some targeted measures to improve the efficiency of insolvency, restructuring, and discharge procedures, especially in shortening their lengths and, therefore, increasing recovery rates. In general, the Directive tries to achieve the balance of interests of creditors and debtors.

While the literature claims that reforms of insolvency regulations positively affect costs and supply of bank lending, to the best of our knowledge, there are no in-depth studies that explore the effect of insolvency regulations on international debt and equity markets. ${ }^{2}$ Therefore, it is not clear, how insolvency regulations affect cross-border debt and equity markets. To which degree do international investors take insolvency regulations into account when they make their investment decisions? Do different types of investors (households, non-financial corporations, banks, and nonbank financial corporations/institutional investors) respond differently to a legal change? Answering these questions is a first step on the way to evaluating the effect of the recent EU regulations on capital market integration in Europe.

In this paper, we assess how improvement in the quality of insolvency regulations affects crossborder investment in debt and equity. For that, we investigate recently conducted reforms of insolvency regulations by the OECD economies (McGowan and Andrews, 2018). The idea is that once the reforms are accomplished, the quality of insolvency regulations improves and investors start investing more in countries with more efficient regulations. For example, better insolvency

\footnotetext{
${ }^{1}$ https://eur-lex.europa.eu/legal-content/EN/TXT/?uri=CELEX $\% 3$ A32019L1023

${ }^{2}$ There are a number of studies that explore the effect of institutional quality on development of international capital markets (for example, Okawa and van Wincoop (2012), Bremus and Kliatskova (2018), among others).
} 
regulations might increase recovery rates and, therefore, make investment in debt securities more attractive. At the same time, introducing pre-insolvency regimes might help restore the value of a distressed enterprise and, thus, attract more investment in its shares.

In a first part of the paper, we use the insolvency regulations index by McGowan and Andrews (2018) that presents the state of insolvency regulations in years 2010 and 2016. We updated the OECD index on insolvency regulations by collecting data on reforms of insolvency regimes in the OECD economies for years 2011-2015. The collected data allows us to see when the reform was conducted and which aspects of insolvency regulations were affected by the reform. This type of data is beneficial as it allows us to look at regulatory changes in insolvency regulations in detail, differentiating between treatment of failed entrepreneurs, prevention and streamlining, as well as availability of restructuring tools.

In a second step, we use the constructed index in a difference-in-difference setup. We assess how legal change affects cross-border debt and equity investment at the sectoral level by comparing cross-border holdings of debt and equity issued by non-financial corporations in countries that implemented insolvency reforms (treatment group) versus countries that did not conduct the reforms (control group) during the period of 2010-2016. We exploit the staggered nature of reforms, i.e. that the reforms are conducted by countries at different points in time and, therefore, some countries serve as a control group prior to the reform and as a treatment group after the reform. For this analysis, we use Securities Holdings Statistics by Sector (SHSS) by the ECB that provides data on nominal and market values of debt and equity securities, with high degree of granularity, such as information by issuer-country, holder-country, as well as holder- and issuer-sector. The data allow us to partition debt and equity that was issued by non-financial corporations, i.e. those firms affected by the reforms of insolvency regulations. ${ }^{3}$ In this setup, we look at the effect of a legal change on cross-border debt and equity investment at a sectoral level assuming that investors, such as households, non-financial corporations, banks, and institutional investors, might have different sensitivity to the legal change.

Our findings suggest that indeed investors take insolvency regulations into account when making

\footnotetext{
${ }^{3}$ Monetary financial institutions usually fall under a separate insolvency regime (IMF, 2005). For example, in the EU, apart from the national insolvency regulations for liquidation of a bank, there is a EU-wide resolution regime as set out in the Bank Recovery and Resolution Directive (BRRD) and Single Resolution Mechanism Regulation (SRMR) for the cases when a failing bank cannot go through normal insolvency proceedings without harming public interest and causing financial instability.
} 
their cross-border investment decisions. The results are in line with the literature that explores the effect of institutional quality on cross-border debt and equity holdings, such as Okawa and van Wincoop (2012), Giofre (2013), and Bremus and Kliatskova (2018). More specifically, investors prefer to invest more in debt and equity of a country that has efficient insolvency regulations in place. The effect, however, varies across sectors. Decisions of institutional investors, households, and non-financial corporations on investment in equity are particularly sensitive to the quality of insolvency regulations. An improvement in insolvency regulations in the issuer-country by one standard deviation is associated with an increase in cross-border equity holdings by $38.8 \%$ to $49.0 \%$, other things being equal. Cross-border debt holdings increase by $37.8 \%$ and $31.0 \%$ for banks and households, respectively. In addition, different aspects of insolvency regulations are not equally important. Availability of pre-insolvency regimes is crucial for shareholders as a timely identification of bankrupt enterprises and early unofficial interventions should increase survival rates and the value of enterprises thereby making investment more attractive. At the same time, availability of debt restructuring tools is important for debt-holders as those help enterprises continue their operations and, therefore, increase possible debt recovery rates. It is worth noting that the observed effects are not driven by the similarity of regulations between issuer- and holder-countries, but rather by improvements in the quality of laws in the issuer-country. Finally, issuer-countries that have developed financial markets and effective government are the ones that benefit (in terms of higher debt and equity inflows) from reforms the most. These cross-border flows are mostly driven by investors from countries with high level of financial development. All in all, our findings are positive about the potential of the recently implemented EU Directive to improve capital market integration in Europe, even though the benefits might spread out across sectors and countries.

Our study is related to two strands of literature. First, multiple cross-country and countryspecific studies show that (changes in) insolvency procedures affect the banking sector, its structure and depth. Haselmann et al. (2009) show that banks increase the supply of credit subsequent to a change in insolvency regulations. The change in collateral law that ensures that individual creditors can realize their claims against a debtor is especially important. Haselmann and Wachtel (2010) show that the legal environment can affect the composition of banks' portfolios, i.e. in countries with efficient insolvency regulations, banks lend more to SMEs and provide more mortgages. At the same time, banks tend to lend to large enterprises and to the public sector in a legal environment that 
is less well-functioning. The results are also confirmed in country studies. By studying bankruptcy reforms in Italy (Rodano et al., 2016) and Brazil (Araujo et al., 2012), the authors show that improvement in creditor rights reduces the cost of debt and spurs lending and, therefore, investment. In contrast to the existing literature, Vig (2013) shows that the securitization reform in India led to a reduction in firms' secured debt, total debt, debt maturity, and asset growth, as well as to an increase in liquidity hoarding by firms by imposing an extra cost on borrowers and, therefore, reducing the willingness of firms to obtain secured debt. Our paper, in turn, contributes to the existing literature by assessing how insolvency regulations affect cross-border debt and equity investment, instead of focusing on bank lending.

Second, the paper is related to the gravity literature that analyzes drivers of international investment positions at the sectoral level. Roque and Cortez (2014), Giofre (2017), Galstyan et al. (2016), and Bremus and Kliatskova (2018) look at the determinants of cross-border debt and equity holdings at the sectoral level. These studies mostly concentrate on the effect of standard gravity controls (such as distance, language, etc.) on cross-border investment. Our study contributes by focusing on the sectoral effects of insolvency regulations.

The rest of the paper is organized as follows. Section 2 presents the empirical model together with tested hypotheses and data. Section 3 discusses our main estimation results. Section 4 provides robustness tests and extensions of the analysis. Section 5 concludes.

\section{Empirical analysis}

The goal of this paper is to investigate how insolvency regulations affect cross-border portfolio investment at the sectoral level. We explore changes in insolvency regulations to identify the effects of improvement in the quality of insolvency regimes on cross-border investment behaviour. In the following, we present hypotheses, data, and empirical strategy.

\subsection{Hypotheses}

According to McGowan and Andrews (2018), a number of reforms that impact the timely initiation and resolution of personal and corporate insolvency proceedings were undertaken by the OECD countries between 2010 and 2016. We use these reforms in order to identify the effect of improve- 
ment in insolvency regulations on cross-border portfolio investment. More specifically, we test the following hypotheses.

Hypothesis 1: Investors in country $i$ invest more in debt and equity of a country $j$, if country $j$ improves efficiency of insolvency regulations. We use legal change, i.e. reforms of insolvency regulations, for an identification. We assume that after the reform the quality of insolvency regulations improves and, therefore, international investors are inclined to invest more in debt and equity of the country. The magnitude of the effect is expected to vary with the balance that the reform strikes between the interests of debtors versus those of creditors. We hypothesize that protection of the latter attracts foreign lenders to a greater extent than protection of the former. Reforms that increase debtor protection may, however, still have a positive impact by virtue of removing legal uncertainty, hence reducing risk when the indebted firm is distressed. For our study, it is striking to differentiate between interests of debtors and creditors. For example, reforms of restructuring tools are debtor-friendly as they allow an insolvent firm continue to operate and give it a chance for a successful recovery. At the same time, these reforms, to a lesser degree, are also creditor-friendly as creditors get an opportunity to achieve higher recovery rates after debt restructuring as compared to immediate suspension of firm's operations.

Hypothesis 2: Investors respond more to prevention and streamlining reforms as well as to reforms of available restructuring tools than to treatment of failed entrepreneurs. The mechanisms through which insolvency laws affect cross-border investment are the reduction in compliance costs as well as better quality of information on the financial stance of enterprises that allows investors to make more informed decisions. We assume that investors take into account the availability of pre-insolvency regimes as a timely identification of bankrupt enterprises and early unofficial interventions should increase survival rates and value of enterprises thereby making investment more attractive. It should be especially important for investment in equity as shareholders are usually not interested in bankruptcy of a firm due to significant loss of value of they investment. In addition, availability of debt restructuring tools are important as those help enterprises continue their operations and, therefore, increase possible debt recovery rates. In particular, it should be taken into account by investors in debt due to the difference in liability characteristics of the two asset categories; in case of bankruptcy, creditors are generally paid first. Further, reforms of the treatment of failed enterprises are mostly affecting entrepreneurs, i.e. owners of the business, and, 
therefore, are less important for debt-holders or minor shareholders.

Finally, we do not have a well-defined prior on which sectors are more affected by insolvency regulations. We assume that more sophisticated investors, such as banks and institutional investors, are more responsive to legal changes as professional investors have more diversified portfolios and, therefore, are more exposed to cross-country differences in legal framework. In addition, professional investors have more capacity to monitor and analyze legal environment (Roque and Cortez, 2014; Bremus and Kliatskova, 2018). Nevertheless, we believe that investment decisions of the other categories of investors, such as households and non-financial corporations, might also be affected by insolvency regimes.

\subsection{Data}

In our study, the sample covers 19 holder-countries and 33 issuer-countries. The coverage is limited to countries that report their securities holdings to the ECB as a part of Securities Holdings Statistics by Sector (SHSS). Holder-countries are Austria, Belgium, Cyprus, Germany, Estonia, Spain, Finland, France, Greece, Ireland, Italy, Lithuania, Luxembourg, Latvia, Malta, Netherlands, Portugal, Slovenia and Slovakia. Issuer-countries are Australia, Austria, Belgium, Canada, Chile, Czech Republic, Estonia, Finland, France, Germany, Greece, Hungary, Ireland, Israel, Italy, Japan, Latvia, Lithuania, Mexico, Netherlands, New Zealand, Norway, Poland, Portugal, Russian Federation, Slovakia, Slovenia, Spain, Sweden, Switzerland, Turkey, United Kingdom and United States. The choice of issuer-countries is limited to the countries for which data on insolvency regulations from the OECD is available. Data sources for all variables are presented in Table A1.

Data on insolvency law reforms. McGowan and Andrews (2018) developed an aggregate indicator on design of insolvency regimes (further, insolvency index) based on questionnaires answered by all OECD member countries (except Iceland), plus China, Lithuania (which became a member in 2018), Malaysia, and Russia. In total, the data is available for 38 countries. The questions initially spanned over the 1995-2016 period in 5-year intervals, but the response rates only allowed for an analysis of years 2010 and 2016. The insolvency indicator covers detailed aspects of the insolvency reforms and their changes, including the efficiency of the procedures, the differentiated treatment according to the firm size and entrepreneur's probity. The aggregate index is scaled to take the values between zero and one with higher values indicating lower quality of insolvency regulations, 
i.e. insolvency regime may delay the initiation and resolution of proceedings. The aggregate index is decomposed into three (plus one) subcomponents, each divided into two to five features that are explained below.

1. Treatment of failed entrepreneurs:

- Availability and time to discharge, i.e. the number of years a bankrupt enterprise must wait until they are discharged from pre-bankruptcy indebtedness;

- Extent of exemptions of the debtor's assets that are not directly linked to the business (e.g. house, spouse's assets);

A lenient treatment of debtors improves the entrepreneurship environment by giving a second chance to failing entrepreneurs to start a new business. At the same time, if personal costs for failed entrepreneurs are too small, it may create a moral hazard problem as entrepreneurs would get involved more in risky business. This, in turn, may increase risk aversion from investors' side that would also increase costs of credit as well as collateral requirements.

2. Prevention and streamlining:

- Early warning mechanisms, such as training on one's financial situation and counsel in case of difficulties;

- Pre-insolvency regimes, which include assessment of risks and early interventions for informal solutions before official proceedings;

- Special insolvency procedures for SMEs, which may be granted a lighter treatment due to their limited resources;

These tools allow creditors and debtors to intervene earlier before the start of formal insolvency proceedings. In addition, the measures help distinguish temporary difficulty from inevitable bankruptcy, and in case of the latter, speed up and smooth the process, so that resources can be re-allocated faster to productive actors of the economy.

3. Restructuring tools:

- Ability to initiate restructuring from both debtors and creditors; 
- Availability and length of stay on assets, which enables the firm to continue operations and, therefore, increases probability of a successful restructuring;

- Possibility and priority of new financing. While priority rules of debt repayment make the system more predictable, priority for new financing might give an opportunity of successful restructuring of the firm and, therefore, increase its final recovery rate;

- Possibility to "cram-down", i.e. approve restructuring based on a requisite majority rule rather than unanimity, may allow timely restructuring of a firm;

- Treatment of management during restructuring, whose dismissal is assumed to have adverse effects on the timely initiation of restructuring;

Facilitating timely restructuring can help avoid precipitation of a viable firm into insolvency and, therefore, minimizes costs and risks involved in the process as well as frees capital for re-investment.

\section{Other factors:}

- Degree of court involvement, that is to be involved only in necessary cases;

- Distinction between honest and fraudulent bankrupts, which can fine-tune the lenience in entrepreneurs' treatment;

- Rights of employees, which if too rigid, are thought to hamper the process.

All in all, the above mentioned measures are supposed to have a positive effect on capital markets by facilitating a timely restructuring of viable businesses or bankruptcy of failed enterprises when appropriate, thereby increasing possible recovery rates for creditors.

The design of insolvency regimes varies significantly across countries and in time. While some countries have quite efficient frameworks to prevent as well as resolve insolvency (such as France and United Kingdom), others are lagging behind (Figure 1). Comparison of values for years 2010 and 2016 (Figure 2) suggests that efficiency of insolvency rules improved or remained the same in all countries, with the exception of Poland, due to the recently conducted reforms.

In our period of study, 19 countries undertook reforms of their insolvency regulations to varying degrees. We collected information on the year and affected regulations based on the OECD study and national sources. A detailed account per year and country is provided in Table A2. The reforms 
Figure 1: Barriers in insolvency regimes in 2016

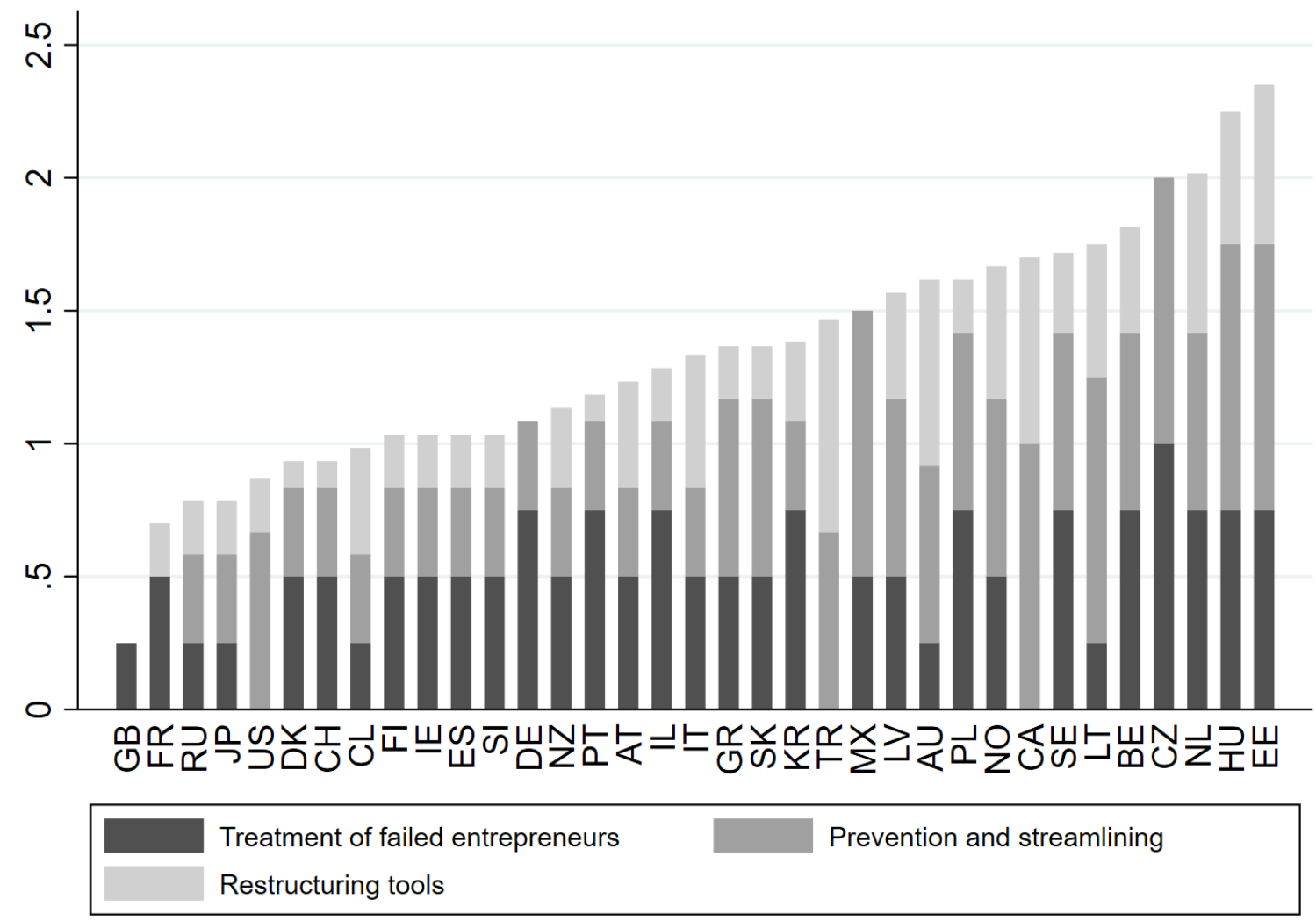

Note: The Figure depicts three components of insolvency regimes: treatment of failed entrepreneurs, prevention and streamlining, and restructuring tools. The sub-indexes are not scaled. Higher index values indicate lower quality of the insolvency regulations. For example, the UK and France have the highest quality of insolvency regulations. Source: OECD.

mostly involved pre-insolvency regimes, the possibility of new financing, and SME-specific procedures. For example, the 2010 German financial stability law allows potentially viable companies not to file for immediate insolvency in case of overindebtedness. In addition, in-court restructuring and creditor participation were improved in 2012. In Italy, debt restructuring and reorganization procedures are alternatives to formal bankruptcy proceedings since 2012, and creditor rights have increased. Finally, while Slovenia did not jump on the bandwagon of reforms in the 1990s, the country introduced various provisions in 2013 and 2015, notably simplifying processes for small enterprises and introducing preventive procedures.

Data on portfolio debt and equity holdings by sectors. ${ }^{4}$ We use confidential bilateral sectoral cross-border portfolio equity and debt holdings at an annual frequency as dependent variables. ${ }^{5}$

\footnotetext{
${ }^{4}$ We thank Deutsche Bundesbank for giving us access to the Securities Holdings Statistics by Sector data.

${ }^{5}$ Debt holdings include long-term and short-term debt securities. Equity holdings include listed shares, excluding
} 
Figure 2: Efficiency of insolvency regulations

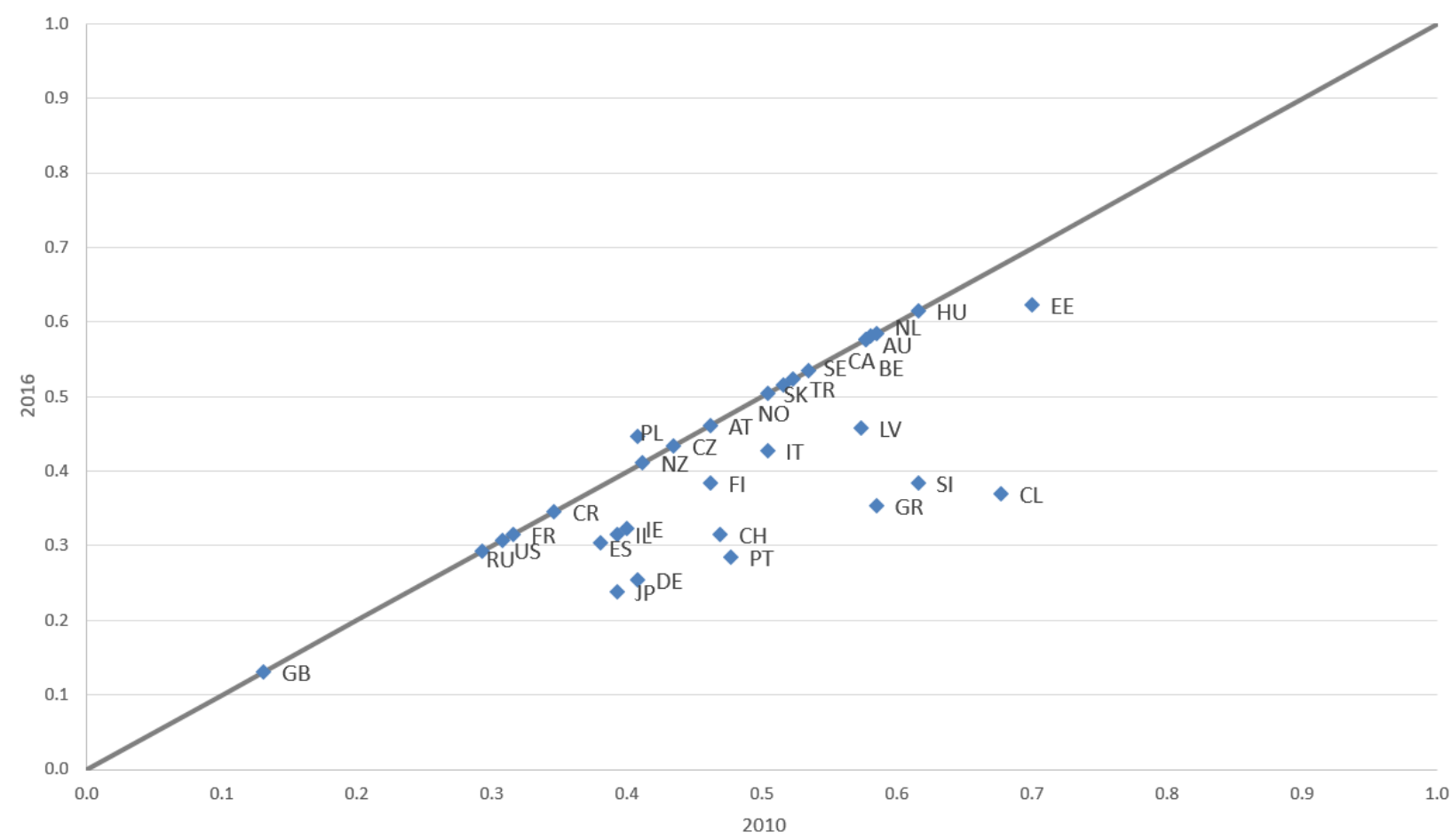

Note: OECD insolvency index (low values = high efficiency), developments between 2010 and 2016 (below the diagonal $=$ improvement, on the diagonal $=$ remained the same). $\mathrm{AT}=$ Austria, $\mathrm{BE}=\mathrm{Belgium}, \mathrm{CZ}=\mathrm{Czech}$ Republic, DE = Germany, EE = Estonia, ES = Spain, FI = Finland, FR = France, GB = United Kingdom, GR $=$ Greece, HU = Hungary, IE = Ireland, IT = Italy, LV = Latvia, NL = Netherlands, PL = Poland, PT = Portugal, $\mathrm{SE}=$ Sweden, $\mathrm{SI}=$ Slovenia, $\mathrm{SK}=$ Slovakia. Source: OECD.

These variables capture security holdings by a sector $s$ of country $i$ that are issued by non-financial corporations in country $j$. The data comes from Securities Holdings Statistics by Sector (SHSS) data of the ECB and is available on a systematic basis starting at the fourth quarter of $2013 .^{6}$

For our analysis, we only consider debt and equity securities issued by non-financial corporations (code S_11 in the SHSS dataset) as insolvency regulations and their changes are affecting insolvency proceeding of the corporates, including SMEs, only. Further, we divide holder-sectors $s$ into the following investor groups ${ }^{7}$ :

- non-financial corporations (code 11);

investment fund shares (ECB, 2015).

${ }^{6}$ Prior to this date, the data was provided to central banks on a voluntary and experimental basis. Therefore, the coverage was incomplete for a number of countries (e.g. for Greece and Spain). Furthermore, only limited quality checks were performed on the data for these periods. In addition, third party holdings and holdings by non-euro area countries showed a very low coverage over this period.

${ }^{7}$ The classification by investor group is available at https://sdw.ecb.europa.eu/datastructure.do? conceptMnemonic=HOLDER_SECTOR\&datasetinstanceid=351\#cl. 
- banks (code 122), including own holdings of monetary financial institutions (MFIs), excluding holdings of foreign banks;

- institutional investors (codes 123-129), including holdings of money market funds, investment companies, insurance corporations, pension funds, and other financial intermediaries;

- households (codes 14-15).

Figure 3: Nominal vs. market value of investments

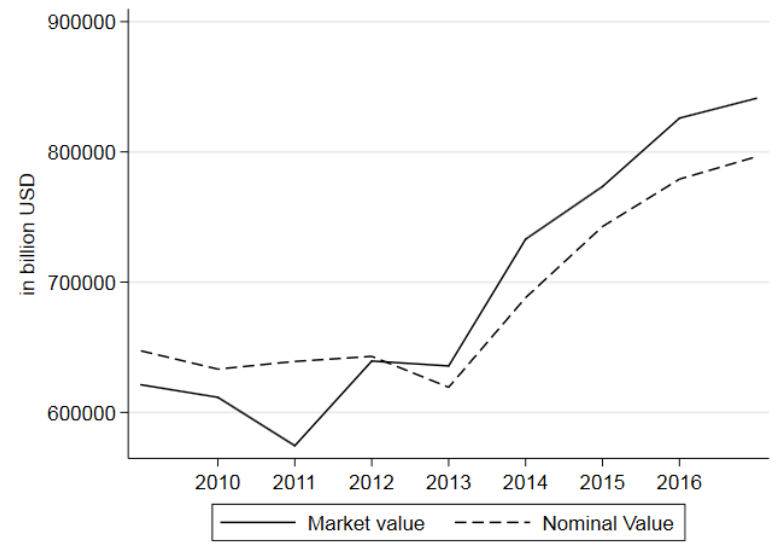

(a) Market vs. nominal value of debt, all countries

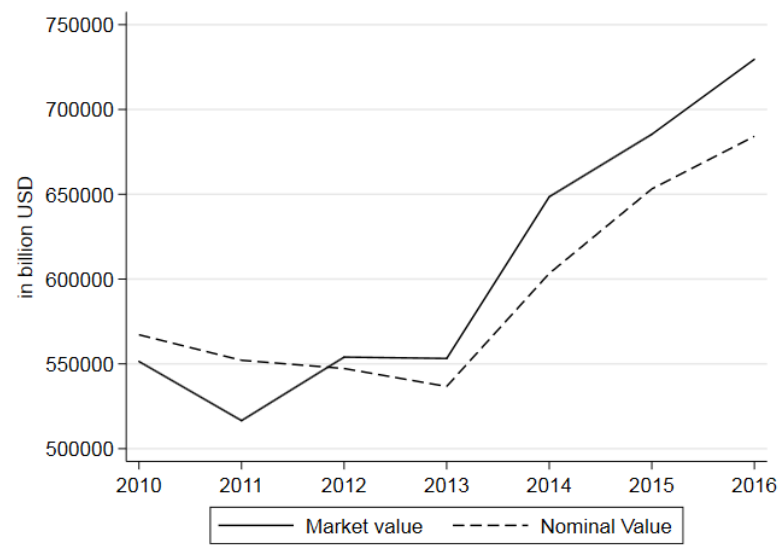

(c) Market vs. nominal value of debt, sample countries

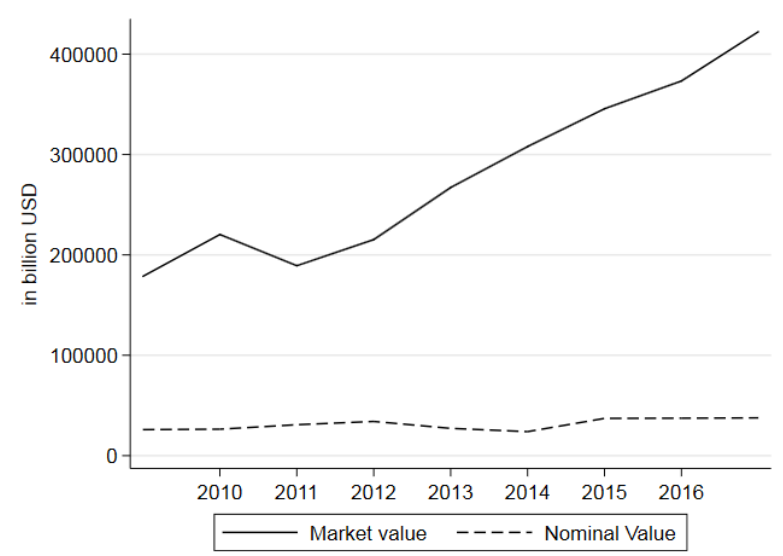

(b) Market vs. nominal value of equity, all countries

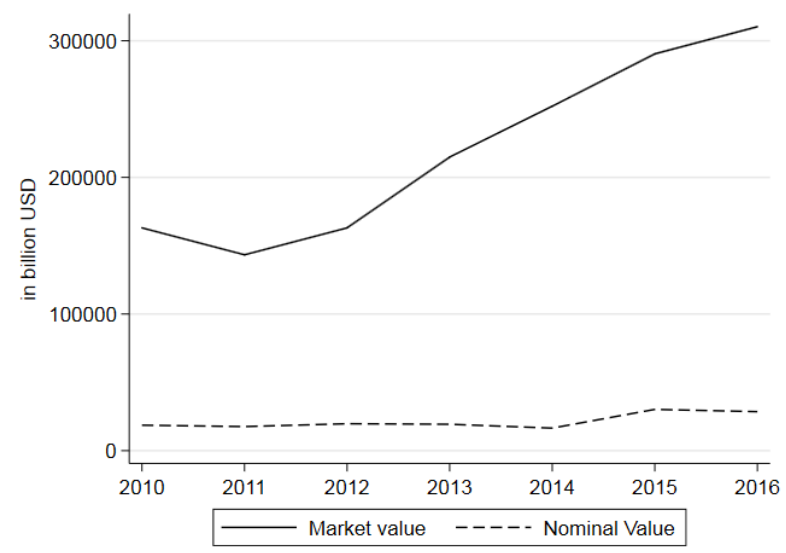

(d) Market vs. nominal value of equity, sample countries

Note: Sample countries are those presented in Table A3. Equity and debt holdings are cross-border holdings, i.e. holdings of country $i$ of securities issued by country $i$ are excluded from the analysis. Source: SHSS, own calculations.

Holdings of the debt and equity by central banks and general government are excluded from the analysis, as we concentrate on behavior of private investors. In addition, we mostly look at nominal 
values of holdings in order to avoid the influence of possible valuation changes that might come from movements in exchange rates or prices. ${ }^{8}$ For our analysis, we only observe whether equity or debt instruments were sold or bought, abstracting from pricing information. ${ }^{9}$ Figure 3 compares market and nominal values for debt and equity, further distinguishing between countries that are part of the sample and all countries reporting SHSS to the ECB. Our sample captures more than $80 \%$ of the total assets. Moreover, when comparing nominal and market values, we observe that valuation changes are mostly an issue for equity investment. The debt investment in market and nominal values almost do not differ, with nominal values being slightly higher than market values before year 2012, and vice versa thereafter.

For debt, the total value increases from 2013. It is worth noting, however, that this might come from a better data coverage due to the change in the SHSS methodology (i.e. reporting to the ECB became compulsory at the fourth quarter of 2013). As expected, the nominal value of debt is less subject to volatility as compared to the market value. For equity, the nominal value is rather stable throughout the observed period. At the same time, the market value follows a clear upward trend and is volatile.

Figure 4: Cross-border debt and equity investment issued by all sectors, by holder-sector

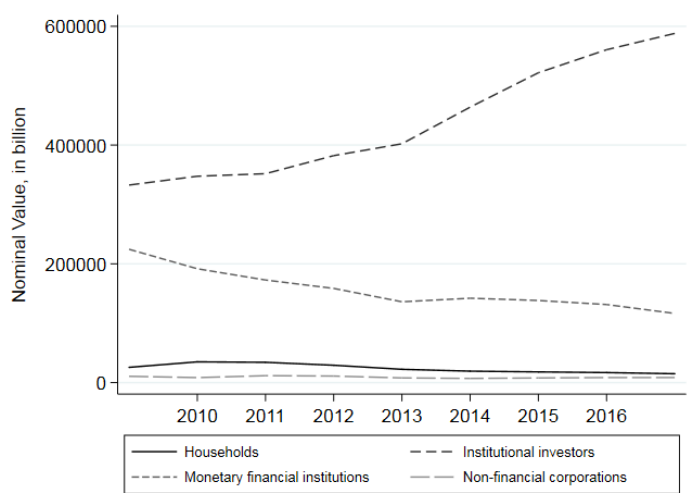

(a) Debt, by holder-sector

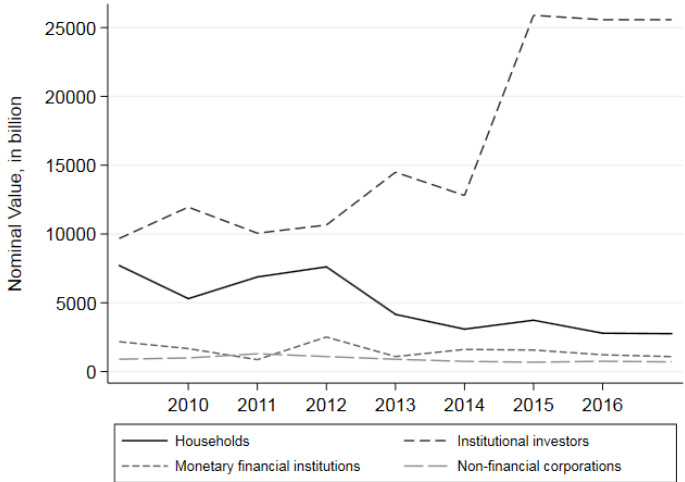

(b) Equity, by holder-sector

Source: SHSS, own calculations.

\footnotetext{
${ }^{8}$ Nominal change in holdings reflects the nominal transaction plus the other nominal volume-driven adjustment (for example, due to reclassifications). Market change in holdings, in addition, includes changes in price and exchange rate adjustments as well as the compound effects (a residual resulting from the simultaneous occurrence of adjustments in market prices and exchange rates and which cannot clearly be ascribed to one of the two causes of adjustment) (Deutsche Bundesbank, 2015).

${ }^{9}$ Most of the other studies that use SHSS data (Buch et al., 2016; Timmer, 2018) use market value of securities holdings as these studies are, in particular, interested in valuation changes, such as changes in price of securities.
} 
Figure 5: Cross-border debt and equity investments issued by non-financial corporations, by holdersector

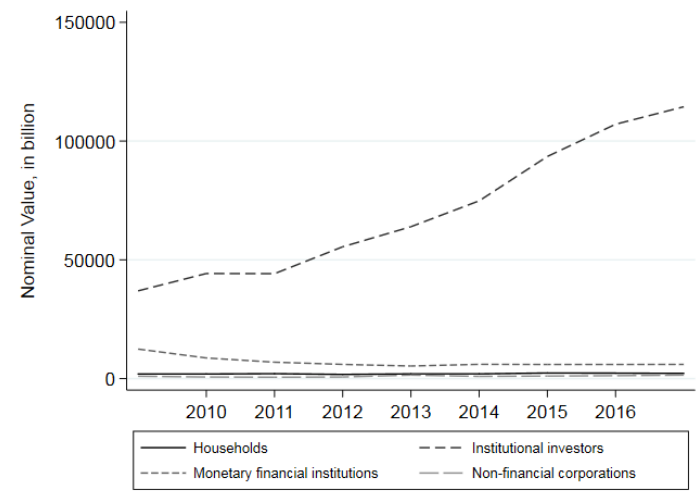

(a) Debt, by holder-sector

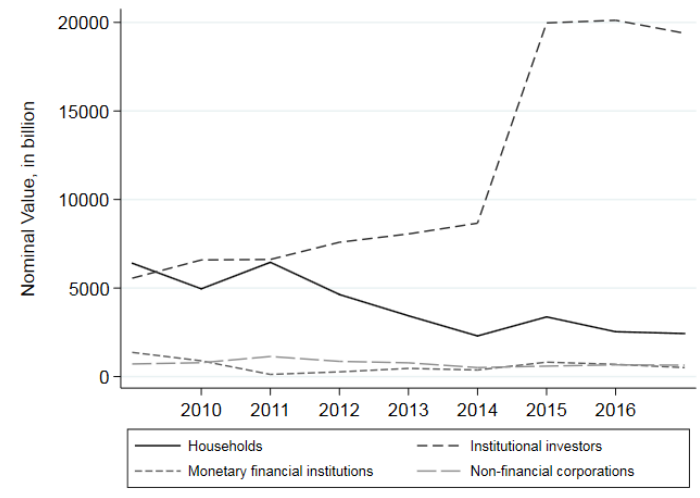

(b) Equity, by holder-sector

Source: SHSS, own calculations.

Further, we compare debt and equity investment by holder-sector of country $i$ issued by all sectors in country $j$ (see Figure 4). Institutional investors and banks are the major holders of debt, while institutional investors and households hold most of the equity. The difference between holder-sector trends is significant: only institutional investors have increased their holdings in both debt and equity, holdings of the latter spiking in 2014 to reach a plateau in 2015. Banks decreased their debt holdings, potentially linked to the progressive introduction of Basel III. Debt holdings of households and non-financial corporations (NFC) remained constant throughout the observed period. For equity, the trend for households' investments is inverse to the one of the institutional investors. Equity holdings of banks and NFCs remained constant. Figure 5 depicts holdings of debt and equity issued by NFCs. The trends are similar to the overall ones.

Control variables. In addition to our main variables of interest, we include a set of control variables in the regression equations. We use standard bilateral gravity controls, such as common legal origin (British, French, German, Scandinavian, or Socialist), log of imports and log of distance (Okawa and van Wincoop, 2012). We assume that countries that have lower distance between each other, have common legal origin, and trade more with each other face lower communication costs as well as decreasing information asymmetries. Therefore, these countries tend to have higher crossborder investment. Following Houston et al. (2012), we include country-specific control variables for issuer-economies such as log of real GDP and financial development index. We expect that 
investors prefer to keep holdings in countries that are rich and have well-developed financial markets. Summary statistics for dependent and explanatory variables are in Table 1.

Table 1: Descriptive Statistics

\begin{tabular}{lcrrrr}
\hline & Obs & Mean & Std.Dev. & Min & Max \\
\hline Dependent Variables & & & & & \\
In nominal value & & & & & \\
Log(E), NFC & 2055 & 12.14 & 3.80 & - & - \\
Log(E), Banks & 1411 & 12.59 & 3.69 & - & - \\
Log(E), II & 2857 & 14.76 & 3.93 & - & - \\
Log(E), HH & 2792 & 12.93 & 3.80 & - & - \\
Log(D), NFC & 1445 & 14.60 & 2.69 & - & - \\
Log(D), Banks & 1753 & 16.72 & 2.51 & - & - \\
Log(D), II & 2601 & 17.62 & 3.13 & - & - \\
Log(D), HH & 2044 & 14.60 & 2.84 & - & - \\
In market value & & & & & \\
Log(E), NFC & 2059 & 14.58 & 3.52 & - & - \\
Log(E), Banks & 1390 & 15.18 & 3.71 & - & - \\
Log(E), II & 2856 & 17.62 & 3.72 & - & - \\
Log(E), HH & 2792 & 15.14 & 3.49 & - & - \\
Log(D), NFC & 1445 & 14.60 & 2.71 & - & - \\
Log(D), Banks & 1753 & 16.77 & 2.54 & - & - \\
Log(D), II & 2605 & 17.66 & 3.15 & - & - \\
Log(D), HH & 2044 & 14.58 & 2.86 & - & - \\
Independent Variables & & & & & \\
Insolvency indicator (lag), issuer & 2856 & 0.44 & 0.13 & 0.13 & 0.70 \\
Log(Real GDP), issuer & 2856 & 28.07 & 2.21 & 23.49 & 33.91 \\
Fin. development index, issuer & 2856 & 0.66 & 0.17 & 0.26 & 0.95 \\
Log(Distance) & 2856 & 7.53 & 1.08 & 4.09 & 9.87 \\
Log(Imports) & 2856 & 20.69 & 2.31 & 12.87 & 25.87 \\
Common legal origin & 2856 & 0.24 & 0.43 & 0.00 & 1.00 \\
\hline
\end{tabular}

Note: Descriptive statistics for independent variables are based on the sample of the baseline regression for nominal value of equity holdings by institutional investors (Table 3 column (3)). For confidentiality reasons, we do not display individual values of investments, such as minima and maxima. $\mathrm{E}=$ Equity, $\mathrm{D}=\mathrm{Debt}$, NFC $=$ Non-Financial Corporations, II = Institutional Investors, $\mathrm{HH}=$ Households.

\section{$2.3 \quad$ Regression specification}

To assess the effect of insolvency law reforms in an issuer-country on investment behavior of different sectors in a holder-country, we apply a difference-in-difference approach. The idea is that after the reform takes place in the issuer-country, quality of insolvency regulations is improved and economic 
agents prefer to invest more in this country. We estimate the following specification of the model (Houston et al., 2012; Haselmann et al., 2009):

$$
\log \left(A_{i_{s} j t}\right)=\alpha_{j}+\alpha_{t}+\alpha_{i t}+\gamma_{1} \text { Treatment }_{j t-1}+\beta X_{i j t}+\beta X_{j t}+\epsilon_{i_{s} j t}
$$

where $i$ indexes holder-country, $j$ indexes issuer-country, and $t$ indexes years. The holder-sector, i.e. banks, institutional investors, non-financial corporations, and households, are denoted as $s$. The logarithm of the nominal value ${ }^{10}$ of debt and equity issued by non-financial corporations is denoted by $A_{i_{s} j t}$. The issuer- and year-fixed effects correspond to $\alpha_{j}$ and $\alpha_{t}$, respectively. All time-varying and time-invariant holder-country characteristics are captured by holder-time dummies $\alpha_{i t}$. The set of control variables includes issuer-specific variables $X_{j t}$, namely the logarithm of real GDP and financial development index (Svirydzenka, 2016), as well as bilateral variables $X_{i j t}$, specifically the logarithm of distance between countries $i$ and $j$, logarithm of trade, and common legal origin

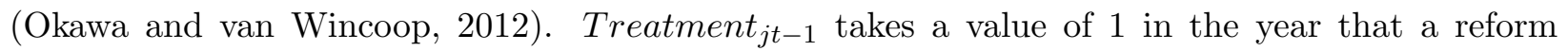
takes place and thereafter, and 0 otherwise. We expect $\gamma_{1}$ to have a positive sign as after the reform of insolvency regulations investors should be willing to invest more in debt and equity of the issuer-country.

Further, we account for the intensity of a regulatory change, i.e. which aspects of the law were changed and how much. For that, we use the insolvency index by McGowan and Andrews (2018) and estimate the following specification of the model (Houston et al., 2012; Haselmann et al., 2009):

$$
\log \left(A_{i_{s} j t}\right)=\alpha_{j}+\alpha_{t}+\alpha_{i t}+\gamma_{2} \text { InsLaws }_{j t-1}+\beta X_{i j t}+\beta X_{j t}+\epsilon_{i_{s} j t}
$$

where InsLaws It-1 $_{1}$ is the insolvency index, where higher values indicate worse quality of regulations. We estimate regressions for the composite index of insolvency laws that is based on 13 aspects of insolvency procedures as well as for sub-indexes of insolvency laws, namely treatment of failed entrepreneurs, prevention and streamlining, and restructuring tools (McGowan and Andrews, 2018). Our coefficient of interest is $\gamma_{2}$, that captures the sensitivity of the dependent variable to the change in insolvency procedures. We expect it to have a negative sign as improvement in the

\footnotetext{
${ }^{10}$ For robustness checks, we also provide estimation results in market value. We use nominal value in the baseline specification to avoid valuation changes of debt and equity securities.
} 
quality of insolvency procedures should provide incentives to economic agents to invest more in the assets of the country. In each regression, standard errors are clustered at a holder-country level.

Our baseline sample covers 19 euro area holder-countries and 33 issuer-countries for the 20102017 period. The difference-in-difference methodology described above allows countries to undergo treatment, i.e. implement a reform of insolvency procedures, at different points in time. As highlighted by Haselmann et al. (2009), multiple pre-intervention and post-intervention time periods take care of many threats concerning validity. Suppose a country $A$ implements a reform in 2012, hence it will be part of the treatment group. Yet, since other countries undergo reforms (i.e. treatment) before it does, it serves as a control group up until its reform year, and as a treatment group thereafter. If country $B$ implements a reform prior to 2010 or does not implement reforms at all during the observed period, it serves as a control group. Overall, the sample contains a control group (19 issuer-countries) that did not experience any reforms of insolvency laws in the 2010-2016 period and a treatment group (19 countries) that undertook reforms of different aspects of insolvency procedures during the aforementioned period. The list of countries is provided in the Appendix Table A3.

As mentioned by Haselmann et al. (2009), the difference-in-difference approach is meaningful if treatment and control groups share similar characteristics. Our sample consists of the OECD and EU countries that are similar in a number of dimension, such as being open market economies with highly developed financial markets and strong institutions. We further check existence of pretrends (Table 4), showing that, after controlling for pull and push factors, treatment and control groups did not exhibit any difference in term of their cross-border equity and debt holdings prior to the reforms. Further, the reforms of insolvency laws should be exogenous to identify a casual link between reforms and cross-border asset holdings. In many of the EU countries, legal change was induced by external pressures from the EU. In addition, endogeneity of legal reforms is less of a concern in our setup as insolvency regulations are usually changed due to high non-performing loans or high amount of zombie firms and bankruptcies of the non-financial corporations (McGowan and Andrews, 2018) rather than pressure from the side of international investors. 


\section{Regression results}

In this section, we present the results of our empirical analysis. First, we report the effect of legal change on the cross-border investment in debt and equity for different holder-country sectors. Second, we look at a more granular picture and investigate changes of which aspects of insolvency regulations matter the most. Finally, we present a number of robustness checks and model extensions.

Baseline specification. We begin our analysis with estimating equation 1 for different holdercountry sectors, with a variable of interest taking the value 1 in the year of the reform and thereafter, and 0 otherwise. Figure 6 and Table 2 present the results for both nominal and market values of debt and equity as a dependent variable. The coefficients on the treatment dummy show whether undertaking reforms triggered a response from foreign holder-countries in terms of investment. The results cannot assert that overall foreign holder-countries increase investments in debt and equity when the issuer-country undertakes an insolvency reform. On average, only for the institutional investors equity holdings increase significantly in both market and nominal value after the reform. The economic impact of a legal change on cross-border investment is considerable; an improvement of a legal indicator implies an increase in cross-border equity holdings by $30.9 \%$ in nominal value. ${ }^{11}$ These results are comparable to the findings of Haselmann et al. (2009) on the effect of insolvency reforms on banking credit.

A more fine-grained picture is provided by our second specification, where we use the insolvency index that measures the quality of insolvency regulations. The higher the index is, the lower the quality of regulations. Subsequent the reform, we expect the quality of regulations to improve, i.e. the index to go down. Figure 7 and Table 3 provide the results. Assessing the effect of qualitative changes captured by the index, we find highly significant responses in nominal values of equity investment from institutional investors and households, and to a lesser extent from NFCs and banks. ${ }^{12}$ The effect is much less pronounced for debt holdings, with coefficients for banks and households holdings being statistically significant at $5 \%$ and $10 \%$, respectively. Looking at the market value of investment holdings, only institutional investors increase their equity holdings and banks their debt holdings following an improvement in insolvency regime. The market value

\footnotetext{
${ }^{11}$ The effect of dummy variables in a semilogarithmic equation is $\exp \left(\gamma_{1}\right)-1$.

${ }^{12} \mathrm{Keep}$ in mind that the index is inversely proportional to the quality of the insolvency regulations: negative coefficients mean that investments respond favourably to improvements in law.
} 
Figure 6: Coefficients on treatment dummy by sector and instrument

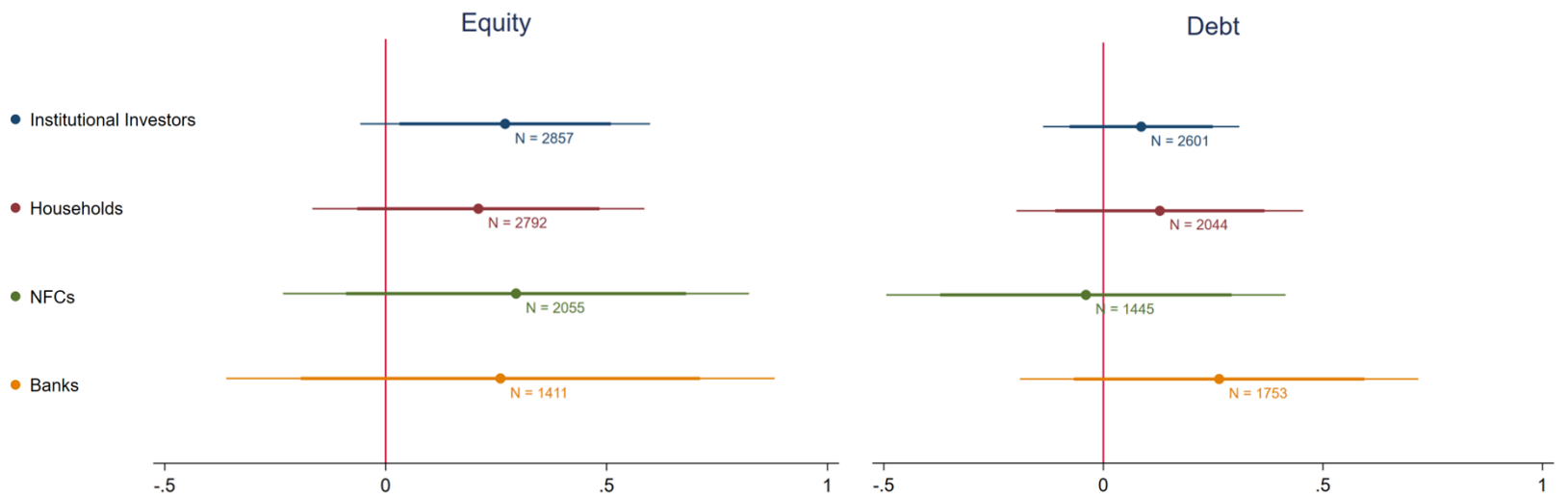

Note: The Figure presents coefficients on a treatment dummy based on the estimation of the equation 1 , with logarithm of nominal value of debt and equity holdings as dependent variables. Full estimation results are presented in Table 2. Treatment Th-1 $_{j-1}$ takes value 1 in the year that insolvency reform takes place and thereafter, and 0 otherwise. Confidence intervals are at the $99 \%$ (thin line) and 95\% (thick line) levels.

of equity and debt holdings, however, incorporates pricing information that we want to abstract from. Economic significance of the results is challenging to interpret as our explanatory variable is an index in a range between zero and one. An improvement in insolvency regulations in the issuercountry by one standard deviation is associated with an increase in cross-border equity holdings by $38.8 \%$ to $49.0 \%$, other things being equal. For cross-border debt holdings, the increase is by $37.8 \%$ and $31.0 \%$ for banks and households, respectively.

Figure 7: Coefficient on insolvency index by sector and instrument

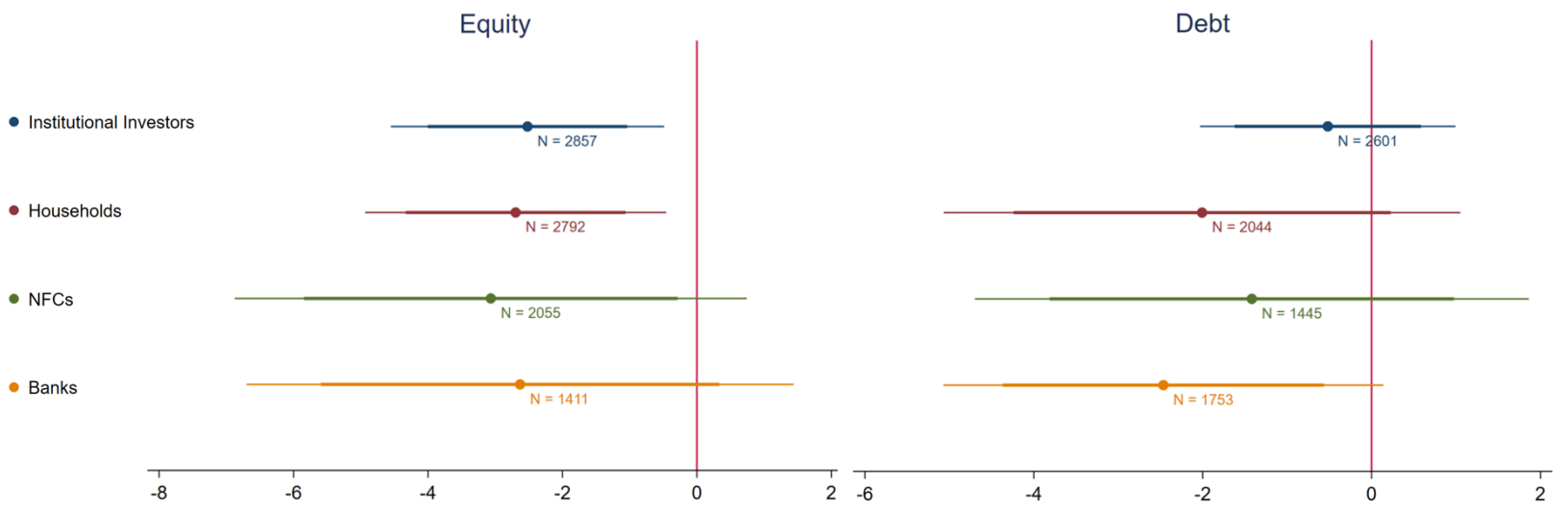

Note: The Figure presents coefficients on insolvency index based on the estimation of the equation 2. Full estimation results are presented in Table 3, with logarithm of nominal value of debt and equity holdings as dependent variables. The insolvency index is an index based on 13 aspects of insolvency procedures, grouped as treatment of failed entrepreneurs, prevention and streamlining, and restructuring tools (McGowan and Andrews, 2018). Higher values of the index indicate worse quality of laws. Confidence intervals are at the $99 \%$ (thin line) and 95\% (thick line) levels. 
These baseline results stress that while overall benefits of the insolvency reforms are nonnegligible, the response they trigger varies greatly by sector. Propensity to invest increases significantly for institutional investors, which form the largest sector in equity holdings in recent years. The high response of households and non-financial corporations in equity investment partly contradicts our expectation that professional players would be more sensitive to reforms, but can be pointing to the reassuring effect of such reforms on small market players. Smaller and less significant coefficients for cross-border debt investment might signal that aspects of insolvency regulations, namely early identification of insolvency and ability of NFC to continue their operations while in distress, might be more important for shareholders as compared to debt-holders.

To address the issue of reverse causality, we study the dynamic effects of the change in the quality of insolvency regulations on cross-border debt and equity investment. To that goal, we use the lags of the insolvency index as well as the actual values and a one-year lead of the insolvency index (Table 4). The coefficients for a one-year lead of the insolvency index are not statistically significant, suggesting that legal changes in this sample were not anticipated. This reassures us about the absence of the reverse causality. The fact that we find some significant coefficients for the year when the reforms took place is not surprising as some of the reforms were adopted at the beginning of the year and, therefore, might have had an effect straight away. As in the baseline regressions, coefficients on one-year lags of insolvency regulations mostly retain their values and statistical significance, with the exception of regressions with equity and debt holdings of banks as dependent variables.

Different types of the insolvency regulations. Further, we distinguish between different types of insolvency regulations, i.e. treatment of failed entrepreneurs, prevention and streamlining, and restructuring tools. As discussed above, we assume that the effects of reforming different aspects of insolvency regulations might be heterogeneous. For example, well-functioning pre-insolvency regimes might be especially important for shareholders as that increases survival rates and the value of enterprises. At the same time, availability of restructuring tools might be mostly taken into account by debt-holders as this aspect of insolvency regime has a potential to increase debt recovery rates.

For cross-border equity holdings, the results are presented in Figure 8a and Table A4. Indeed, as suggested by our second hypothesis, prevention and streamlining is the most significant component affecting equity holdings across sectors (although the effect for banks is only statistically significant 
Table 2: Baseline regression in a dummy form

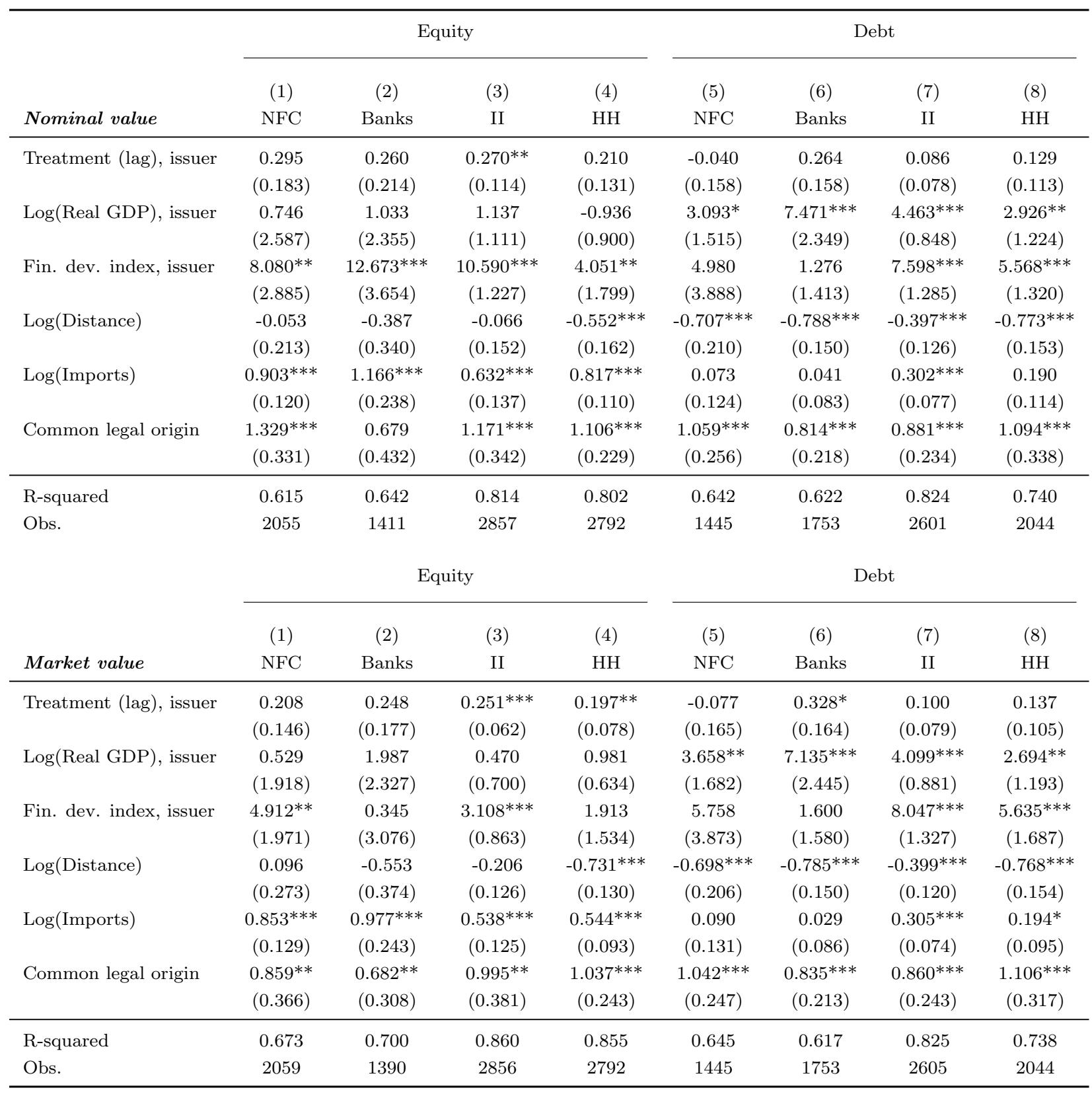

${ }^{*} p<0.1,{ }^{* *} p<0.05,{ }^{* * *} p<0.01$. Standard errors in brackets.

Note: This Table presents estimation results for log bilateral portfolio debt and equity assets in market and nominal values based on equation 1. Holder-year, year- and issuer- fixed effects are included in all regressions. Standard errors are clustered at the holder-country level. $\mathrm{E}=$ Equity, $\mathrm{D}=$ Debt, $\mathrm{NFC}=$ Non-Financial Corporations, II $=$ Institutional Investors, $\mathrm{HH}=$ Households.

at the $5 \%$ level). Availability of early warning mechanism and pre-insolvency regimes (i.e. early informal interventions before formal proceedings) seem to be the most important aspects. At the same time, special insolvency procedures for SMEs seem not to be taken into account. It is not 
Table 3: Baseline regression in an index form

\begin{tabular}{|c|c|c|c|c|c|c|c|c|}
\hline \multirow{2}{*}{ Nominal value } & \multicolumn{4}{|c|}{ Equity } & \multicolumn{4}{|c|}{ Debt } \\
\hline & $\begin{array}{c}(1) \\
\text { NFC }\end{array}$ & $\begin{array}{c}(2) \\
\text { Banks }\end{array}$ & $\begin{array}{l}(3) \\
\text { II }\end{array}$ & $\begin{array}{l}(4) \\
\mathrm{HH}\end{array}$ & $\begin{array}{c}(5) \\
\text { NFC }\end{array}$ & $\begin{array}{c}(6) \\
\text { Banks }\end{array}$ & $\begin{array}{l}(7) \\
\text { II }\end{array}$ & $\begin{array}{l}(8) \\
\mathrm{HH}\end{array}$ \\
\hline Insolvency indicator (lag), issuer & $\begin{array}{c}-3.066^{* *} \\
(1.323)\end{array}$ & $\begin{array}{c}-2.630^{*} \\
(1.404)\end{array}$ & $\begin{array}{c}-2.520^{* * *} \\
(0.706)\end{array}$ & $\begin{array}{c}-2.696^{* * *} \\
(0.778)\end{array}$ & $\begin{array}{l}-1.418 \\
(1.139)\end{array}$ & $\begin{array}{c}-2.466^{* *} \\
(0.905)\end{array}$ & $\begin{array}{l}-0.518 \\
(0.525)\end{array}$ & $\begin{array}{l}-2.007^{*} \\
(1.063)\end{array}$ \\
\hline $\log ($ Real GDP), issuer & $\begin{array}{c}1.200 \\
(2.614)\end{array}$ & $\begin{array}{c}1.347 \\
(2.360)\end{array}$ & $\begin{array}{c}1.463 \\
(1.094)\end{array}$ & $\begin{array}{l}-0.510 \\
(0.898)\end{array}$ & $\begin{array}{c}3.410^{* *} \\
(1.515)\end{array}$ & $\begin{array}{c}7.678^{* * *} \\
(2.366)\end{array}$ & $\begin{array}{c}4.503^{* * *} \\
(0.868)\end{array}$ & $\begin{array}{c}3.250^{* *} \\
(1.265)\end{array}$ \\
\hline Fin. dev. index, issuer & $\begin{array}{c}8.718^{* * *} \\
(2.948)\end{array}$ & $\begin{array}{c}13.090^{* * *} \\
(3.587)\end{array}$ & $\begin{array}{c}11.355^{* * *} \\
(1.338)\end{array}$ & $\begin{array}{c}4.667^{* *} \\
(1.688)\end{array}$ & $\begin{array}{c}5.219 \\
(4.002)\end{array}$ & $\begin{array}{c}1.853 \\
(1.433)\end{array}$ & $\begin{array}{c}7.758^{* * *} \\
(1.262)\end{array}$ & $\begin{array}{c}6.177^{* * *} \\
(1.525)\end{array}$ \\
\hline Log(Distance) & $\begin{array}{l}-0.051 \\
(0.214)\end{array}$ & $\begin{array}{l}-0.387 \\
(0.340)\end{array}$ & $\begin{array}{l}-0.066 \\
(0.152)\end{array}$ & $\begin{array}{c}-0.553^{* * *} \\
(0.163)\end{array}$ & $\begin{array}{c}-0.702^{* * *} \\
(0.211)\end{array}$ & $\begin{array}{c}-0.785^{* * *} \\
(0.150)\end{array}$ & $\begin{array}{c}-0.397^{* * *} \\
(0.126)\end{array}$ & $\begin{array}{c}-0.770^{* * *} \\
(0.153)\end{array}$ \\
\hline $\log ($ Imports $)$ & $\begin{array}{c}0.903^{* * *} \\
(0.121)\end{array}$ & $\begin{array}{c}1.163^{* * *} \\
(0.239)\end{array}$ & $\begin{array}{c}0.632^{* * *} \\
(0.137)\end{array}$ & $\begin{array}{c}0.816^{* * *} \\
(0.110)\end{array}$ & $\begin{array}{c}0.076 \\
(0.124)\end{array}$ & $\begin{array}{c}0.043 \\
(0.083)\end{array}$ & $\begin{array}{c}0.303^{* * *} \\
(0.077)\end{array}$ & $\begin{array}{c}0.193 \\
(0.114)\end{array}$ \\
\hline Common legal origin & $\begin{array}{c}1.331^{* * *} \\
(0.332)\end{array}$ & $\begin{array}{c}0.683 \\
(0.429)\end{array}$ & $\begin{array}{c}1.171^{* * *} \\
(0.343)\end{array}$ & $\begin{array}{c}1.110^{* * *} \\
(0.229)\end{array}$ & $\begin{array}{c}1.055^{* * *} \\
(0.256)\end{array}$ & $\begin{array}{c}0.812^{* * *} \\
(0.218)\end{array}$ & $\begin{array}{c}0.882^{* * *} \\
(0.234)\end{array}$ & $\begin{array}{c}1.094^{* * *} \\
(0.339)\end{array}$ \\
\hline $\begin{array}{l}\text { R-squared } \\
\text { Obs. }\end{array}$ & $\begin{array}{l}0.616 \\
2055\end{array}$ & $\begin{array}{c}0.643 \\
1411\end{array}$ & $\begin{array}{l}0.815 \\
2857\end{array}$ & $\begin{array}{c}0.802 \\
2792\end{array}$ & $\begin{array}{c}0.642 \\
1445\end{array}$ & $\begin{array}{c}0.623 \\
1753\end{array}$ & $\begin{array}{l}0.824 \\
2601\end{array}$ & $\begin{array}{l}0.741 \\
2044\end{array}$ \\
\hline \multirow{2}{*}{ Obs. } & \multicolumn{4}{|c|}{ Equity } & \multicolumn{4}{|c|}{ Debt } \\
\hline & $(1)$ & $(2)$ & (3) & (4) & $(5)$ & $(6)$ & (7) & (8) \\
\hline Market value & NFC & Banks & II & $\mathrm{HH}$ & NFC & Banks & II & $\mathrm{HH}$ \\
\hline Insolvency indicator (lag), issuer & $\begin{array}{l}-1.423 \\
(0.986)\end{array}$ & $\begin{array}{l}-1.439 \\
(1.276)\end{array}$ & $\begin{array}{c}-1.271^{* * *} \\
(0.417)\end{array}$ & $\begin{array}{l}-0.803 \\
(0.532)\end{array}$ & $\begin{array}{l}-1.169 \\
(1.141)\end{array}$ & $\begin{array}{c}-2.799^{* * *} \\
(0.948)\end{array}$ & $\begin{array}{l}-0.587 \\
(0.527)\end{array}$ & $\begin{array}{l}-2.023^{*} \\
(1.016)\end{array}$ \\
\hline $\log ($ Real GDP $)$, issuer & $\begin{array}{c}0.717 \\
(1.947)\end{array}$ & $\begin{array}{c}2.105 \\
(2.329)\end{array}$ & $\begin{array}{c}0.581 \\
(0.688)\end{array}$ & $\begin{array}{c}1.041 \\
(0.625)\end{array}$ & $\begin{array}{c}3.954^{* *} \\
(1.693)\end{array}$ & $\begin{array}{c}7.351^{* * *} \\
(2.466)\end{array}$ & $\begin{array}{c}4.144^{* * *} \\
(0.899)\end{array}$ & $\begin{array}{c}3.016^{* *} \\
(1.234)\end{array}$ \\
\hline Fin. dev. index, issuer & $\begin{array}{c}5.284^{* *} \\
(2.078)\end{array}$ & $\begin{array}{c}0.748 \\
(3.019)\end{array}$ & $\begin{array}{c}3.518^{* * *} \\
(0.849)\end{array}$ & $\begin{array}{c}2.194 \\
(1.472)\end{array}$ & $\begin{array}{c}5.921 \\
(3.964)\end{array}$ & $\begin{array}{c}2.287 \\
(1.597)\end{array}$ & $\begin{array}{c}8.227^{* * *} \\
(1.298)\end{array}$ & $\begin{array}{c}6.249^{* * *} \\
(1.880)\end{array}$ \\
\hline Log(Distance) & $\begin{array}{c}0.096 \\
(0.273)\end{array}$ & $\begin{array}{l}-0.552 \\
(0.374)\end{array}$ & $\begin{array}{l}-0.205 \\
(0.126)\end{array}$ & $\begin{array}{c}-0.731^{* * *} \\
(0.130)\end{array}$ & $\begin{array}{c}-0.693^{* * *} \\
(0.207)\end{array}$ & $\begin{array}{c}-0.782^{* * *} \\
(0.150)\end{array}$ & $\begin{array}{c}-0.398^{* * *} \\
(0.120)\end{array}$ & $\begin{array}{c}-0.766^{* * *} \\
(0.154)\end{array}$ \\
\hline Log(Imports) & $\begin{array}{c}0.854^{* * *} \\
(0.129)\end{array}$ & $\begin{array}{c}0.977 * * * \\
(0.244)\end{array}$ & $\begin{array}{c}0.539^{* * *} \\
(0.125)\end{array}$ & $\begin{array}{c}0.545^{* * *} \\
(0.093)\end{array}$ & $\begin{array}{c}0.093 \\
(0.131)\end{array}$ & $\begin{array}{c}0.031 \\
(0.087)\end{array}$ & $\begin{array}{c}0.306^{* * *} \\
(0.074)\end{array}$ & $\begin{array}{l}0.197^{*} \\
(0.094)\end{array}$ \\
\hline Common legal origin & $\begin{array}{c}0.858^{* *} \\
(0.365)\end{array}$ & $\begin{array}{c}0.679^{* *} \\
(0.307)\end{array}$ & $\begin{array}{c}0.995^{* *} \\
(0.381)\end{array}$ & $\begin{array}{c}1.037^{* * *} \\
(0.243)\end{array}$ & $\begin{array}{c}1.038^{* * *} \\
(0.248)\end{array}$ & $\begin{array}{c}0.834^{* * *} \\
(0.213)\end{array}$ & $\begin{array}{c}0.860^{* * *} \\
(0.243)\end{array}$ & $\begin{array}{c}1.106^{* * *} \\
(0.318)\end{array}$ \\
\hline R-squared & 0.673 & 0.700 & 0.860 & 0.855 & 0.645 & 0.618 & 0.825 & 0.739 \\
\hline Obs. & 2059 & 1390 & 2856 & 2792 & 1445 & 1753 & 2605 & 2044 \\
\hline
\end{tabular}

$* p<0.1,{ }^{* *} p<0.05, * * * p<0.01$. Standard errors in brackets.

Note: This Table presents estimation results for log bilateral portfolio debt and equity assets in market and nominal values based on equation 2. Holder-year, year- and issuer- fixed effects are included in all regressions. Standard errors are clustered at the holder-country level. $\mathrm{E}=$ Equity, $\mathrm{D}=$ Debt, $\mathrm{NFC}=$ Non-Financial Corporations, II $=$ Institutional Investors, $\mathrm{HH}=$ Households.

surprising as SMEs are usually not issuing shares and, therefore, are not subject of interest to investors in equity. Finally, the other aspects of insolvency regulations, such as restructuring tools and treatment of failed entrepreneurs, appear to be less important for equity-holders. 
Table 4: Testing for a parallel trends assumption

\begin{tabular}{|c|c|c|c|c|c|c|c|c|}
\hline & \multicolumn{4}{|c|}{ Equity } & \multicolumn{4}{|c|}{ Debt } \\
\hline & (1) & $(2)$ & $(3)$ & $(4)$ & (5) & (6) & (7) & (8) \\
\hline & NFC & Banks & II & HH & NFC & Banks & II & $\mathrm{HH}$ \\
\hline \multirow[t]{2}{*}{ Insolvency index (lead), issuer } & -0.251 & 0.573 & 0.188 & 1.125 & -2.132 & -1.470 & 0.459 & 1.162 \\
\hline & $(1.904)$ & $(2.407)$ & $(0.696)$ & $(1.538)$ & $(2.404)$ & $(1.880)$ & $(0.958)$ & $(0.735)$ \\
\hline \multirow[t]{2}{*}{ Insolvency index, issuer } & -0.550 & $-4.491^{* *}$ & $-1.323^{*}$ & -1.513 & 1.059 & -2.382 & -0.529 & 0.625 \\
\hline & $(1.829)$ & $(1.703)$ & $(0.691)$ & $(0.977)$ & $(1.713)$ & $(1.428)$ & $(0.748)$ & $(1.164)$ \\
\hline \multirow[t]{2}{*}{ Insolvency index (lag), issuer } & -1.293 & -0.489 & $-1.627^{* *}$ & $-1.968^{*}$ & $-2.082^{*}$ & -1.690 & $-0.739^{*}$ & $-2.091^{* *}$ \\
\hline & $(1.293)$ & $(1.473)$ & $(0.566)$ & $(1.087)$ & $(1.065)$ & $(1.023)$ & $(0.409)$ & $(0.936)$ \\
\hline \multirow[t]{2}{*}{ Insolvency index (lag, t-2), issuer } & -1.342 & -1.737 & 0.447 & 0.269 & $3.356^{*}$ & 2.947 & 0.015 & 1.354 \\
\hline & $(1.500)$ & $(1.694)$ & $(0.587)$ & $(1.028)$ & $(1.825)$ & $(1.732)$ & $(0.501)$ & $(1.171)$ \\
\hline \multirow{2}{*}{ Log(Real GDP), issuer } & 0.092 & $5.948^{*}$ & $2.133^{*}$ & -0.212 & $6.381^{* * *}$ & 3.052 & $3.925^{* * *}$ & 3.146 \\
\hline & $(3.755)$ & $(3.088)$ & $(1.056)$ & $(1.110)$ & $(2.052)$ & $(2.207)$ & $(1.109)$ & $(1.820)$ \\
\hline \multirow[t]{2}{*}{ Fin. development index, issuer } & $9.851^{* *}$ & $19.421^{* * *}$ & $9.561^{* * *}$ & 3.684 & $9.486^{*}$ & -0.386 & $6.792^{* * *}$ & $5.196^{* *}$ \\
\hline & $(3.479)$ & $(3.828)$ & $(1.794)$ & $(2.491)$ & $(4.579)$ & $(2.108)$ & $(1.759)$ & $(2.259)$ \\
\hline \multirow[t]{2}{*}{ Log(Distance $)$} & -0.065 & -0.307 & -0.006 & $-0.574^{* * *}$ & $-0.596^{* *}$ & $-0.766^{* * *}$ & $-0.372^{* * *}$ & $-0.652^{* * *}$ \\
\hline & $(0.180)$ & $(0.351)$ & $(0.172)$ & $(0.183)$ & $(0.206)$ & $(0.168)$ & $(0.125)$ & $(0.157)$ \\
\hline \multirow[t]{2}{*}{ Log(Imports) } & $0.884^{* * *}$ & $1.191^{* * *}$ & $0.621^{* * *}$ & $0.810^{* * *}$ & 0.140 & 0.018 & $0.301^{* * *}$ & $0.274^{* *}$ \\
\hline & $(0.129)$ & $(0.302)$ & $(0.157)$ & $(0.126)$ & $(0.137)$ & $(0.097)$ & $(0.083)$ & $(0.128)$ \\
\hline \multirow[t]{2}{*}{ Common legal origin } & $1.357^{* * *}$ & 0.791 & $1.123^{* * *}$ & $1.121^{* * *}$ & $1.032^{* * *}$ & $0.836^{* * *}$ & $0.886^{* * *}$ & $1.037^{* *}$ \\
\hline & $(0.361)$ & $(0.527)$ & $(0.327)$ & $(0.249)$ & $(0.230)$ & $(0.212)$ & $(0.259)$ & $(0.364)$ \\
\hline R-squared & 0.621 & 0.659 & 0.815 & 0.809 & 0.660 & 0.627 & 0.829 & 0.764 \\
\hline Obs. & 1368 & 945 & 1891 & 1839 & 989 & 1167 & 1728 & 1358 \\
\hline
\end{tabular}

$$
{ }^{*} p<0.1,{ }^{* *} p<0.05, * * * p<0.01 \text {. Standard errors in brackets. }
$$

Note: This Table presents estimation results for log bilateral portfolio debt and equity assets in nominal value based on equation 2. Holder-year, year- and issuer- fixed effects are included in all regressions. Standard errors are clustered at the holder-country level. $\mathrm{E}=$ Equity, $\mathrm{D}=\mathrm{Debt}, \mathrm{NFC}=$ Non-Financial Corporations, II $=$ Institutional Investors, $\mathrm{HH}=$ Households.

Figure 8b and Table A5 present the results for cross-border debt holdings. As expected, availability of restructuring tools is the most important aspect that affects investment decisions of both households and banks. The two subcomponents, i.e. availability of length of stay as well as possibility and priority of new financing, appear to be the crucial ones. Availability of length of stay, that is, continuation of operations by firm in distress, increases the probability of a subsequent successful restructuring. Priority for new financing, further, allows a distressed firm attract additional financing on good terms and, therefore, increases the probability of recovery. Apart form that, prevention and streamlining as well as treatment of failed entrepreneurs seem to be viable factors for banks. 


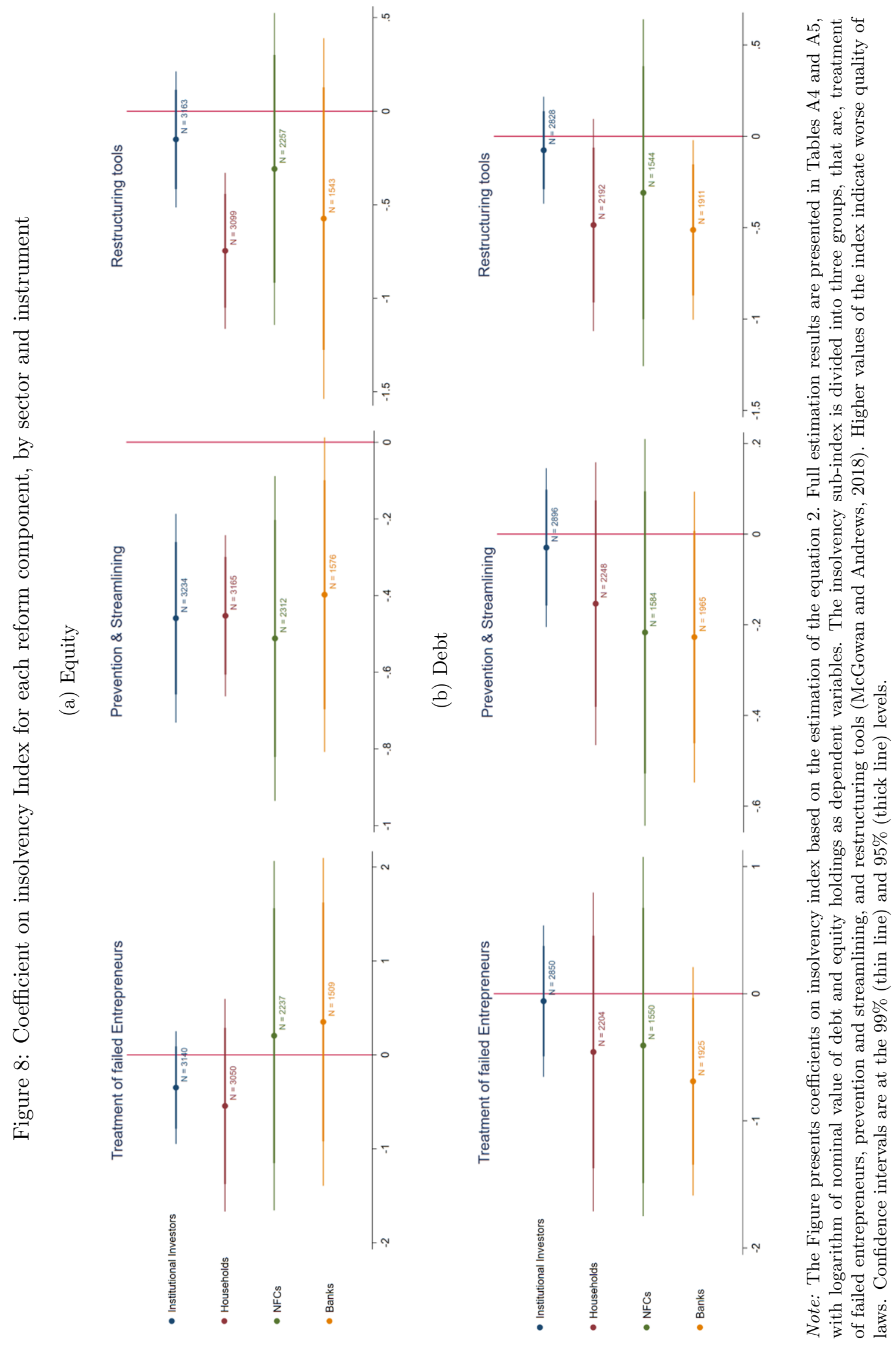




\section{Robustness checks and extensions of the model}

Robustness checks. In this section, we explore the sensitivity of our results to sample composition, potential outliers and alternative clustering of standard errors. The regression outputs are not reported, but are available upon request. First, we check whether the results remain intact when we change the sample composition. For that, we exclude issuer-countries, holder-countries, and years one-by-one. This way, we want to ensure that our results are not driven by individual countries or a particular sample period. The results are mostly unaffected by this alternative specification.

Second, we winsorize the sample at $5 \%$ for the dependent variables, in order to remove potential outliers at both sides of the distribution. Winsorizing the sample leaves significance levels unchanged (with the exception of bank holdings of equity). The coefficients become a bit smaller for the equity holdings of institutional investors, households, and NFCs. At the same time, coefficients for debt holdings equations are not significantly affected.

Finally, we consider different approaches for estimating the standard errors in our panel data regressions. Clustering standard errors by issuer-country rather than holder-country changes results at the margin, by increasing standard errors and decreasing significance levels of the equity holdings coefficients. Clustering by country pairs yields identical results to our baseline.

Similarity of laws. So far, we tested whether improvement in the quality of insolvency regulations as a result of reforms affects cross-border debt and equity holdings. Further, we check whether it is the similarity of a holder-country's insolvency regime with that of the issuer-country that drives the effect. We assume that when countries $i$ and $j$ have similar insolvency regulations, it is easier for investors to interpret the laws and the level playing field is more understandable for them. Therefore, they might be willing to increase their investment in countries with similar regulations.

We calculated two similarity indexes. The first index captures whether countries have similar regulations in place in the $n=13$ subcomponents of the insolvency regulations. The similarity index is built from dummies that are equal to one when issuer- and holder-countries share similar regulations in each subcomponent. Thereby, the similarity index is an integer between 0 and 13 , with higher values implying more similar regulations. The index is calculated as follows: 


$$
\text { SimilarityIndex }_{i j t}=\sum_{n=1}^{13}\left[\text { InsLaws }_{n i t}=\text { InsLaw }_{n j t}\right]
$$

The second index is a dissimilarity index that is calculated as an absolute value of a difference between each issuer- and holder-country subcomponent of insolvency regulations. The index ranges between 0.25 and 9.45. In this case, the higher the value of the index is, the less similar insolvency regimes between two countries are. The index is calculated as follows:

$$
\text { DissimilarityIndex }_{i j t}=\sum_{n=1}^{13} a b s\left(\text { InsLaws }_{n i t}-\text { InsLaw }_{n j t}\right)
$$

The results are presented in Table A6. We find no significant effect of the similarity of regulations on cross-border debt and equity investment, independently of whether we use a similarity or dissimilarity index. At the same time, the coefficients on the reform remain almost intact. In fact, when controlling for dissimilarity of regulations, the propensity to invest in equity from institutional investors doubles, at the same level of significance. This results suggest that our main findings stem from the improvement in insolvency regimes in the issuer-country, rather than from the holder-country's potential familiarity with the issuer-country's insolvency regulations.

Heterogeneity of holders. We test whether the observed effect of insolvency regulations on crossborder debt and equity holdings varies with holder-country characteristics, like the development of financial markets (Svirydzenka, 2016) or quality of governance (Kaufmann et al., 2010). ${ }^{13}$ We assume that investors that come from countries with well-developed financial markets would be more sensitive to the quality of insolvency regulations in a counterparty country as these investors are, in general, more open to international investments (Desbordes and Wei, 2017; Hyun and Kim, 2010). In addition, investors that reside in countries with effective government might have higher quality standards and higher demands for regulatory environment in an issuer-country. To test this hypothesis, we interact the insolvency index with a dummy variable that is equal to 1 when financial market development (or government effectiveness) is above the sample median in year 2009, and 0 otherwise. Indeed, investors from countries with well-developed financial markets invest more in

\footnotetext{
${ }^{13}$ The financial development index by Svirydzenka (2016) assesses the depth, accessibility and efficiency of financial markets. The index on quality of governance by Kaufmann et al. (2010), within the World Bank Worldwide Governance Indicators, assesses the perceptions of government performance (public services, civil service, policy formulation and implementation, credibility of commitment) from household and firm surveys. The index ranges from approximately -2.5 to 2.5 , with higher values indicating better quality of governance.
} 
both debt and equity of countries with high quality of insolvency regulations (Table A7). The results for government effectiveness are statistically insignificant, indicating that quality of governance in a home country does not affect cross-border investment decisions. From a policy perspective, our results suggest that investors from countries with well-developed financial markets would be the ones that drive capital markets integration as a result of improvement in insolvency regulations.

Heterogeneity of issuers. Further, we check whether quality of insolvency regulations affects cross-border investments differently depending on characteristics of the country that conducted insolvency reforms. In this case, we look at the financial development and government effectiveness of issuer-countries. Countries with high level of financial development have more liquid markets with plenty of investment opportunities. Therefore, removal of some impediments, such as ineffective insolvency regulations, might have a stronger effect. In addition, countries that have an effective government, i.e. one that implements policies with a high degree of commitment and credibility, might achieve better results after implementing reforms as an effective government signals a high degree of law enforcement. Indeed, when reforms of insolvency regulations are implemented by countries that are financially developed and have an effective government, the effect of such reforms becomes more pronounced (Table A8). It is important for equity investment by all sectors as well as debt investment by institutional investors. All in all, the results suggest that development of financial markets and good quality of government in an issuer-country are the key for successful reforms.

\section{Conclusion}

Should a company be on the verge of bankruptcy or simply face financial distress, a well-defined insolvency regime goes a long way in removing uncertainty for both investors and management. With this in mind, the EU Directive 2019/1023 has set initial steps towards a common framework with minimum standards in early restructuring and discharge of debt. The literature has widely documented the effect insolvency reforms on banking. Efficient insolvency procedures are associated with an increase in credit supply Haselmann et al. (2009), notably to SMEs, diversification of portfolio (Haselmann and Wachtel, 2010), and lower risk-taking (Fang et al., 2014). Going a step further, our study provides insights on two grounds: we analyze the effects of insolvency reforms on 
foreign players, and from an investment point of view, on debt and equity. Further we decompose this effect by holder-sectors.

Relying on the OECD data on insolvency regimes and ECB SHSS data on cross-border investments, we identify a causal effect within each sector and each instrument through a differencein-difference approach. Our results suggest that foreign investors are more likely to invest in a country if its insolvency regime is efficient. Investors are particularly sensitive to improvement in prevention, streamlining, and restructuring tools. However, the marginal effect is not homogeneous across sectors. Institutional investors and households seem to be the most reactive in their equity investments after such reforms, while banks react in debt holdings. At the same time, non-financial corporations seem to react less in their equity investments. Further, we find evidence that, for equities, all sectors are highly sensitive to measures related to prevention and streamlining, while debt-holders mostly take into account restructuring tools.

Overall, whilst the effect varies with sectors and instruments, insolvency reforms do exert a positive effect on cross-border investments, thereby deepening the capital markets integration. Still, our results remain agnostic in terms of the optimal insolvency regime and, hence, leave manoeuvre for decision-makers to choose the design of the reform. Indeed, academic views do not necessarily converge on the content of the reforms, notably in terms of creditor- versus debtor-friendliness (Kliatskova and Savatier, 2019). Therefore, an optimal design of insolvency regulations can be an interesting question that we leave for future research. 


\section{References}

Araujo, A. P., Ferreira, R. V., and Funchal, B. (2012). The brazilian bankruptcy law experience. Journal of Corporate Finance, 18(4):994-1004.

Bremus, F. and Kliatskova, T. (2018). Legal harmonization, institutional quality, and countries' external positions: A sectoral analysis. DIW Discussion Paper 1768.

Bremus, F. and Kliatskova, T. (2019). More efficient insolvency regulations could increase financial markets' resilience. In A Stable and Social Europe, number 16 - 17 - 18 in Weekly Report, pages 152-153. DIW.

Buch, C., Koetter, M., and Ohls, J. (2016). Banks and sovereign risk: A granular view. Journal of Financial Stability, 25:1-15.

Desbordes, R. and Wei, S.-J. (2017). The effects of financial development on foreign direct investment. Journal of Development Economics, 127:153-168.

Deutsche Bundesbank (2015). Securities holdings statistics for analysing holdings of securities in Germany and Europe: Methodology and results. Deutsche Bundesbank Monthly Report.

ECB (2015). Who holds what? New information on securities holdings. Economic Bulletin, (2).

European Commission (2015a). Action plan on building a Capital Markets Union. COM/2015/0468 final.

European Commission (2015b). Commission staff working document "Initial reflections on the obstacles to the development of deep and integrated EU capital markets". Technical report.

Fang, Y., Hasan, I., and Marton, K. (2014). Institutional development and bank stability: Evidence from transition countries. Journal of Banking \& Finance, 39:160-176.

Galstyan, V., Lane, P. R., Mehigan, C., and Mercado, R. (2016). The holders and issuers of international portfolio securities. Journal of the Japanese and International Economies, 42:100108. 
Giofre, M. (2013). Investor protection rights and foreign investment. Journal of Comparative Economics, 41:506-526.

Giofre, M. (2017). Financial education, investor protection and international portfolio diversification. Journal of International Money and Finance, 71:111-139.

Haselmann, R. and Wachtel, P. (2010). Institutions and bank behavior: Legal environment, legal perception, and the composition of bank lending. Journal of Money, Credit and Banking, 42:965984.

Haselmann, R. F. H., Pistor, K., and Vig, V. (2009). How law affects lending. The Review of Financial Studies, 23(2):549-580.

Houston, J. F., Lin, C., and Ma, Y. (2012). Regulatory arbitrage and international bank flows. The Journal of Finance, 67(5):1845-1895.

Hyun, H. and Kim, H. H. (2010). The determinants of cross-border M\&As: The role of institutions and financial development in the gravity model. The World Economy, 33(2).

IMF (2005). Current Developments in Monetary and Financial Law, volume 3. IMF.

Kaufmann, D., Kraay, A., and Mastruzzi, M. (2010). The worldwide governance indicators: Methodology and analytical issues. World Bank Policy Research Working Paper No. 5430.

Kliatskova, T. and Savatier, L. B. (2019). Insolvency regimes and economic outcomes. DIW Roundup 133.

La Porta, R., de Silanes, F. L., Shleifer, A., and Vishny, R. (1999). The quality of government. Journal of Law, Economics and Organization, 15(1):222-279.

McGowan, M. A. and Andrews, D. (2018). Design of insolvency regimes across countries. OECD Economics Department Working Papers 1504.

Okawa, Y. and van Wincoop, E. (2012). Gravity in international finance. Journal of International Economics, 87(2):205-215.

Rodano, G., Serrano-Velarde, N., and Tarantino, E. (2016). Bankruptcy law and bank financing. Journal of Financial Economics, 120(2):363-382. 
Roque, V. and Cortez, M. C. (2014). The determinants of international equity investment: Do they differ between institutional and noninstitutional investors? Journal of Banking $\&$ Finance, 49:469-482.

Svirydzenka, K. (2016). Introducing a new broad-based index of financial development. IMF Workin Paper WP/16/5.

Timmer, Y. (2018). Cyclical investment behavior across financial institutions. Journal of Financial Economics, 129(2):268-286.

Vig, V. (2013). Access to collateral and corporate debt structure: Evidence from a natural experiment. The Journal of Finance, 68(3):881-928. 


\section{A Appendix}

Table A1: Data description and sources

\begin{tabular}{|c|c|c|c|}
\hline Variable & Unit & Description & Source \\
\hline $\begin{array}{l}\text { Debt and equity } \\
\text { holdings }\end{array}$ & EUR & $\begin{array}{l}\text { Nominal value of debt and equity issued by } \\
\text { non-financial corporations in country } j \text { and } \\
\text { held by sectors } s \text { in country } i \text { at time } t \text {. Hold- } \\
\text { ings with a value below } € 50 \text { were dropped } \\
\text { ( } 2.6 \% \text { of non-missing values) }\end{array}$ & SHSS, ECB \\
\hline $\begin{array}{l}\text { Insolvency index, } \\
\text { issuer }\end{array}$ & {$[0,1]$} & $\begin{array}{l}\text { Index measuring the quality of laws governing } \\
\text { insolvency (and pre-insolvency) procedures }\end{array}$ & $\begin{array}{l}\text { McGowan and An- } \\
\text { drews (2018) }\end{array}$ \\
\hline Real GDP, issuer & $\begin{array}{l}\text { constant } 2010 \text { local } \\
\text { currency unit }\end{array}$ & Real GDP, base year: 2010 & $\begin{array}{l}\text { World } \text { Develop- } \\
\text { ment Indicators, } \\
\text { WB }\end{array}$ \\
\hline $\begin{array}{l}\text { Financial develop- } \\
\text { ment (FD) index, } \\
\text { issuer }\end{array}$ & {$[0,1]$} & $\begin{array}{l}\text { The index summarizes how developed financial } \\
\text { institutions and markets are in terms of their } \\
\text { depth (size and liquidity), access (ability of in- } \\
\text { dividuals and companies to access them), and } \\
\text { efficiency (ability to provide financial services } \\
\text { at low cost, with sustainable revenues and the } \\
\text { level of activity of markets). }\end{array}$ & Svirydzenka (2016) \\
\hline Distance & $\mathrm{km}$ & $\begin{array}{l}\text { Distance between issuer- and holder-countries' } \\
\text { most populated cities }\end{array}$ & CEPII \\
\hline Bilateral trade & mln. USD & Sum of the values of imports and exports, fob & DOTS, IMF \\
\hline $\begin{array}{l}\text { Common legal ori- } \\
\text { gin }\end{array}$ & 0 or 1 & $\begin{array}{l}\text { Dummy that equals to } 1 \text { when the two countries } \\
\text { share the same legal origin (British, French, } \\
\text { German, Scandinavian, Socialist) }\end{array}$ & $\begin{array}{l}\text { La Porta et al. } \\
(1999)\end{array}$ \\
\hline
\end{tabular}




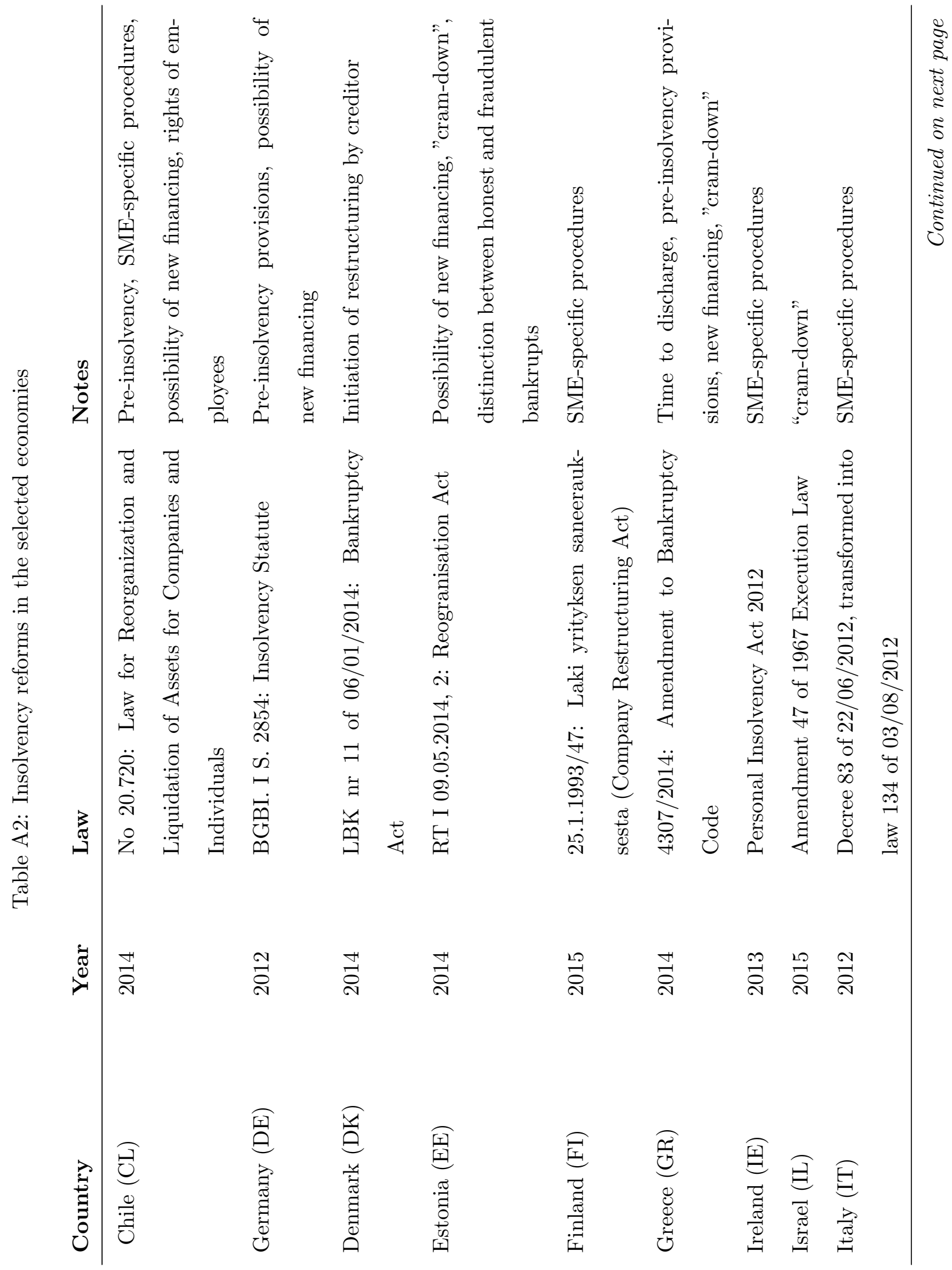




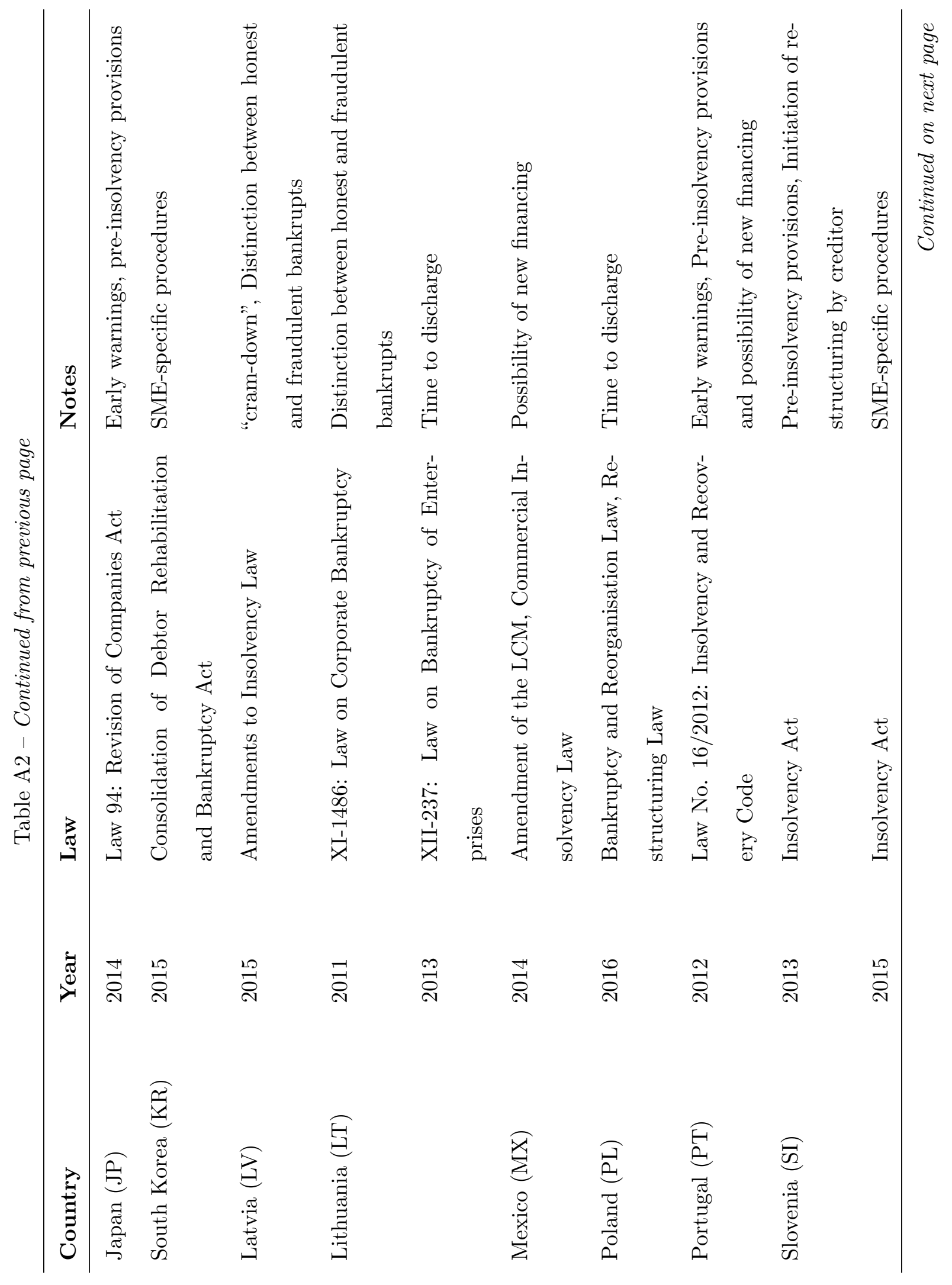




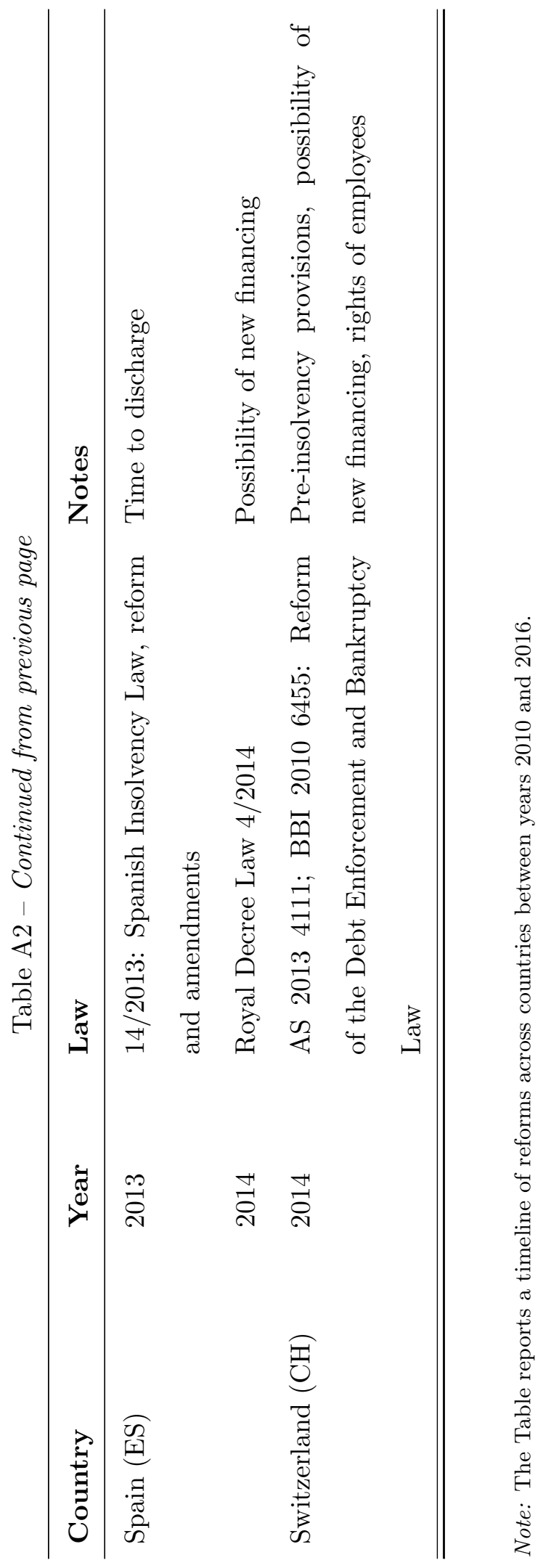


Table A3: List of countries, treatment vs. control groups

\begin{tabular}{ll|ll} 
Country & $\begin{array}{l}\text { Control/Treatment } \\
\text { (year of reform) }\end{array}$ & Country & $\begin{array}{l}\text { Control/Treatment } \\
\text { (year of reform) }\end{array}$ \\
\hline Austria & $\mathrm{C}$ & Italy & $\mathrm{T}(2012)$ \\
Australia & $\mathrm{C}$ & Japan & $\mathrm{T}(2014)$ \\
Belgium & $\mathrm{C}$ & South Korea & $\mathrm{T}(2011)$ \\
Canada & $\mathrm{C}$ & Latvia & $\mathrm{T}(2015)$ \\
Switzerland & $\mathrm{T}(2014)$ & Luxembourg & $\mathrm{T}(2011,2013)$ \\
Chile & $\mathrm{T}(2014)$ & Malaysia & $\mathrm{C}$ \\
China & $\mathrm{C}$ & Mexico & $\mathrm{T}(2014)$ \\
Czech Rep. & $\mathrm{C}$ & Netherlands & $\mathrm{C}$ \\
Germany & $\mathrm{T}(2012)$ & New Zealand & $\mathrm{C}$ \\
Denmark & $\mathrm{T}(2014)$ & Norway & $\mathrm{C}$ \\
Estonia & $\mathrm{T}(2014)$ & Poland & $\mathrm{T}(2016)$ \\
Spain & $\mathrm{T}(2013,2014)$ & Portugal & $\mathrm{T}(2012)$ \\
Finland & $\mathrm{T}(2015)$ & Russian Federation & $\mathrm{C}$ \\
France & $\mathrm{C}$ & Slovakia & $\mathrm{C}$ \\
United Kingdom & $\mathrm{C}$ & Slovenia & $\mathrm{T}(2013,2015)$ \\
Greece & $\mathrm{T}(2014)$ & Sweden & $\mathrm{C}$ \\
Hungary & $\mathrm{C}$ & Turkey & $\mathrm{C}$ \\
Ireland & $\mathrm{T}(2013)$ & United States & \\
Israel & $\mathrm{T}(2015)$ & &
\end{tabular}

Note: Countries reported as a treatment group ( $\mathrm{T})$ are part of the control group (C) prior to the year they adopted the reform. Countries, such as Spain, Lithuania, and Slovenia, conducted reforms step-wise, i.e. different aspects of insolvency regulations (treatment of failed entrepreneurs, prevention and streamlining, restructuring tools) were reformed at different years. 


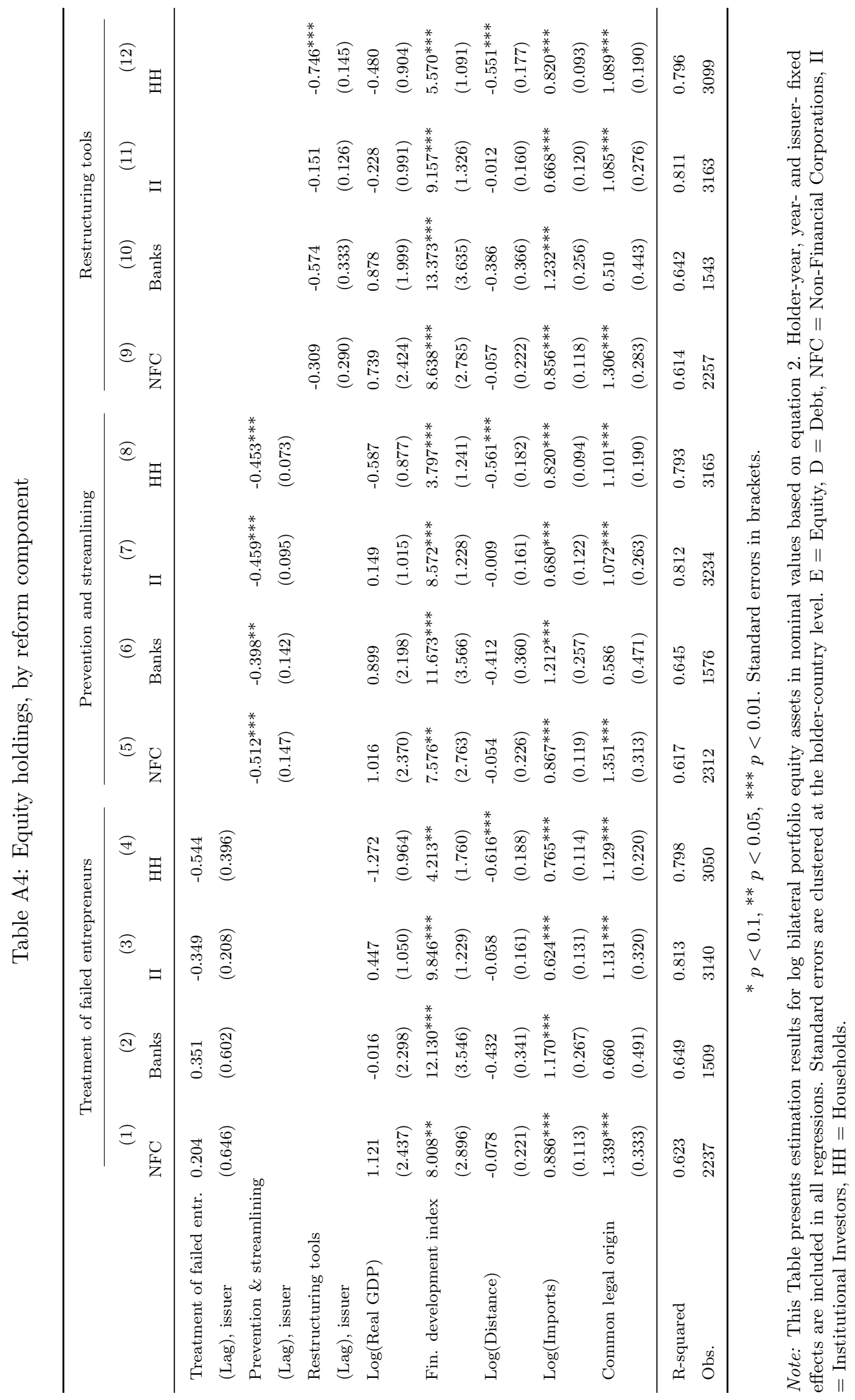




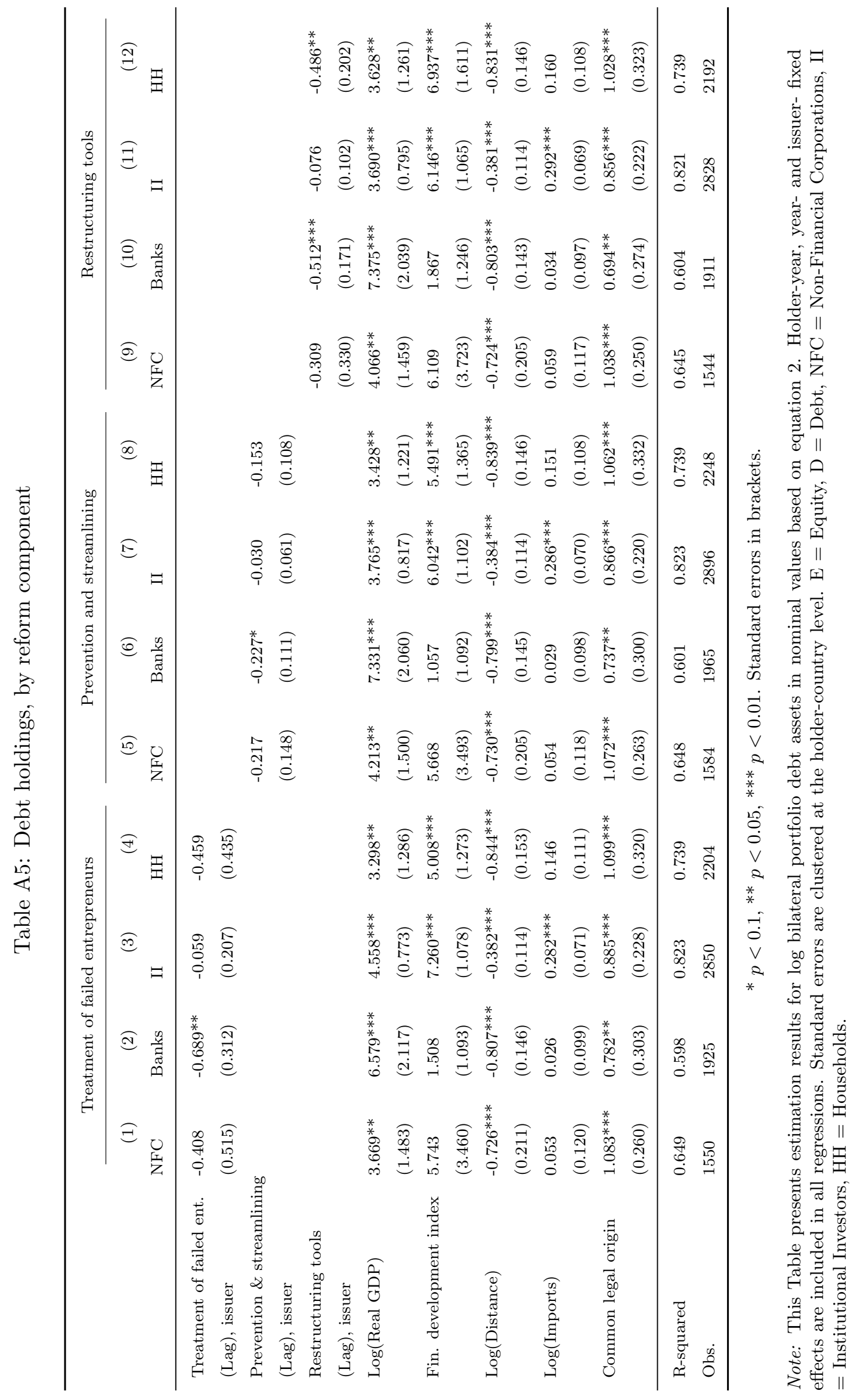




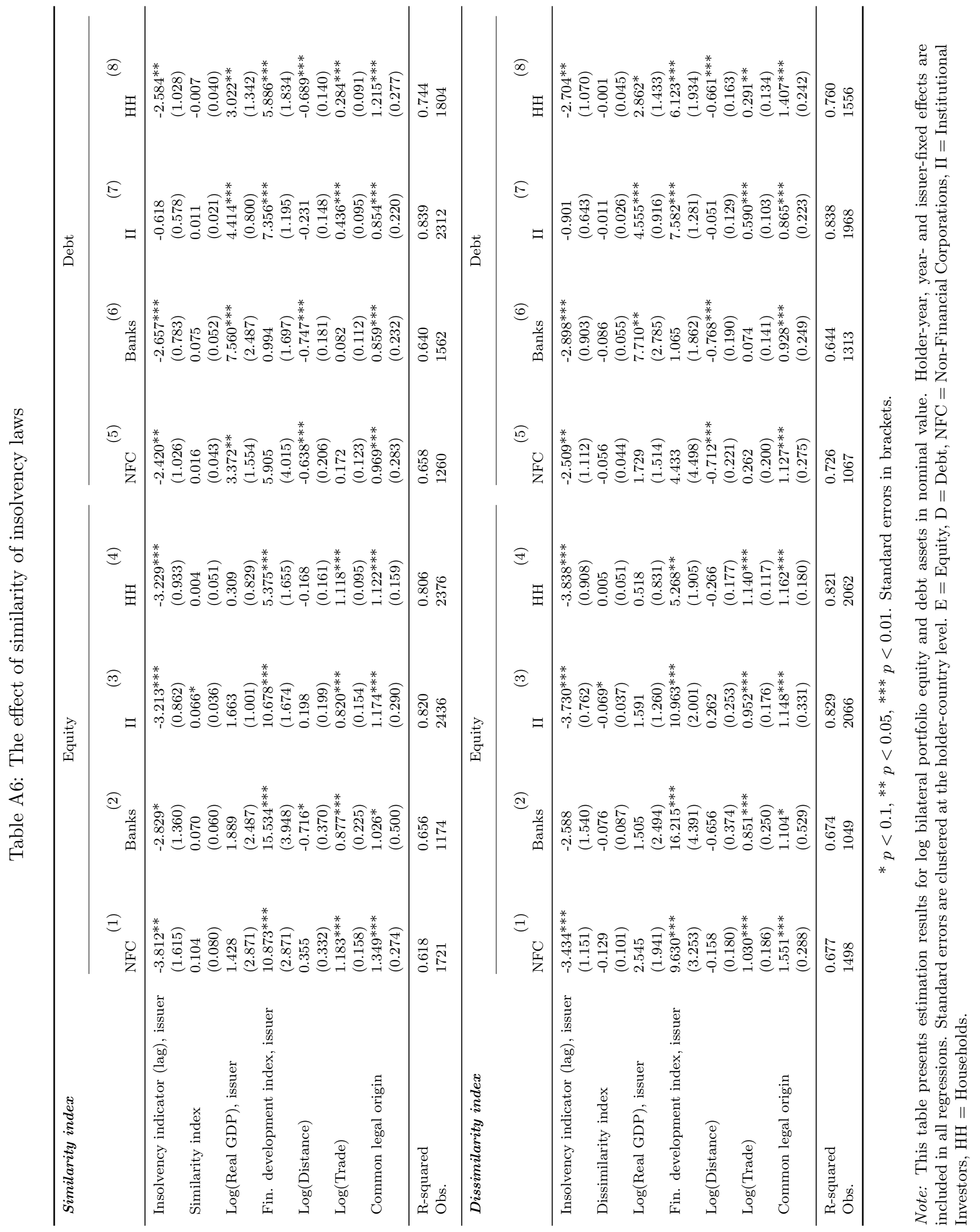




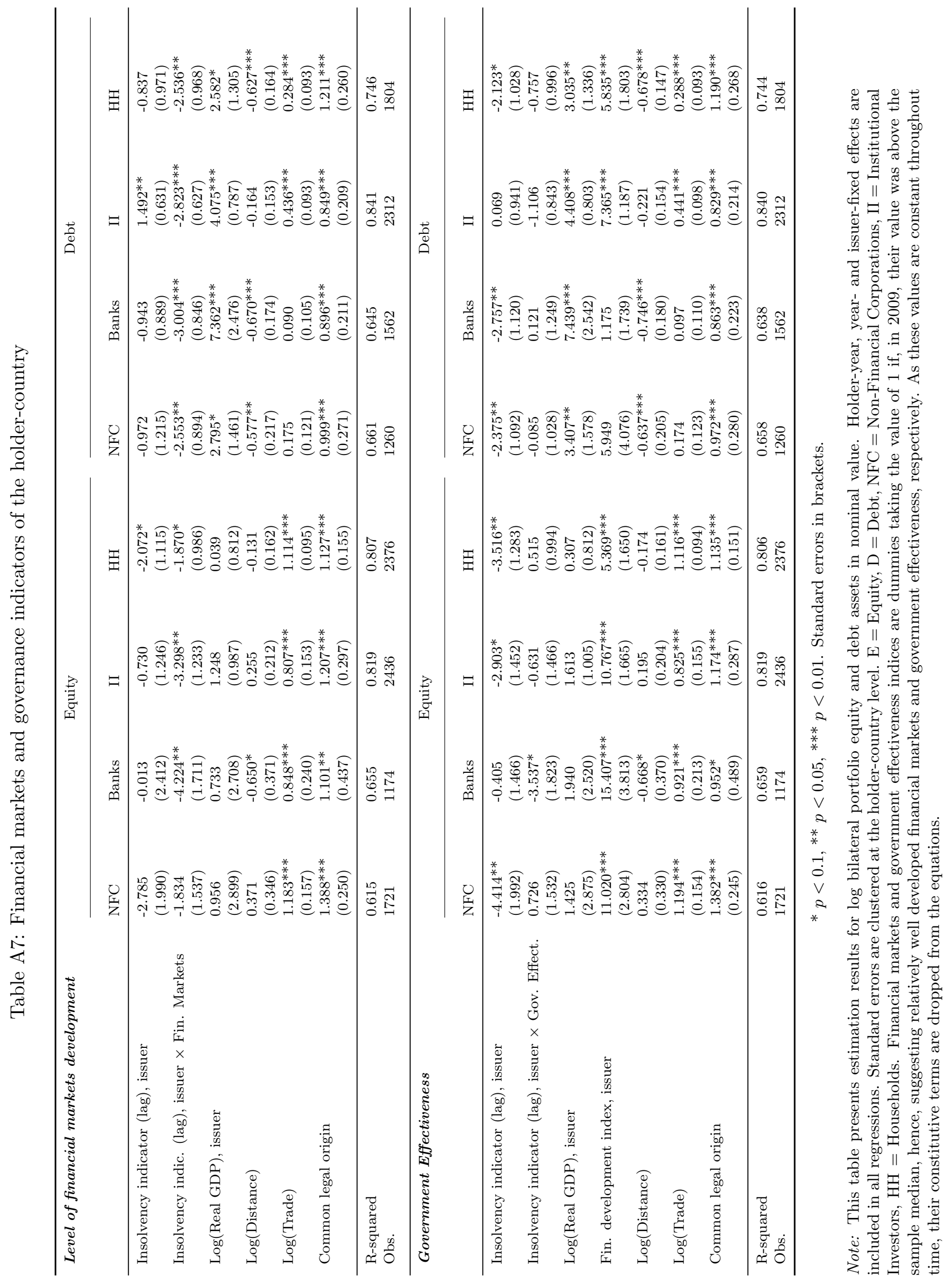




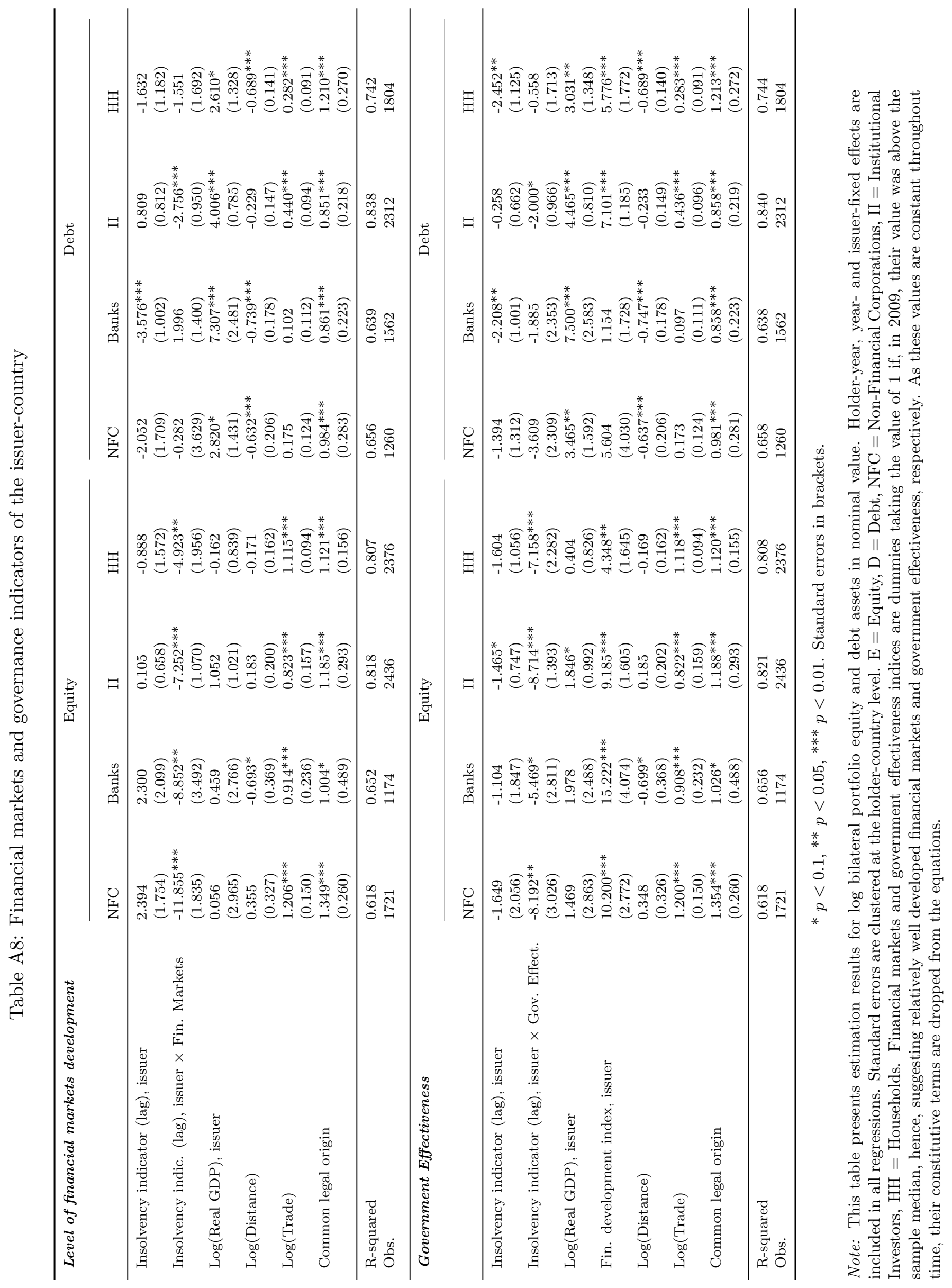

